\title{
Legal Plug-Ins: Cultural Distance, Cross-Listing, and Corporate Governance Reform
}

\author{
By \\ Amir N. Licht*
}

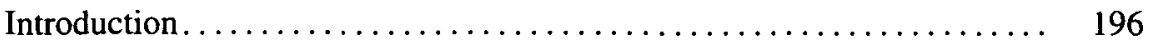

I. Understanding Cross-Listing .................... 200

A. Financial and Business Aspects .............. 200

B. Corporate Governance .................... 202

C. Informational and Cultural Distance ............. 206

II. Understanding Cultural Distance .................. 208

A. Context: Korean Corporate Governance ............ 209

1. A Brief Economic History .................. 209

2. The Chaebol........................ 210

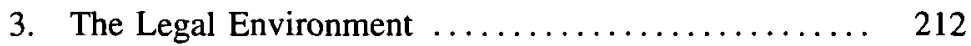

4. The Confucian Heritage ................. 214

B. Comparing Cultures ..................... 215

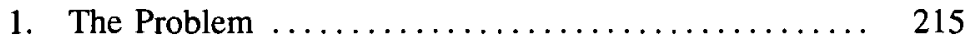

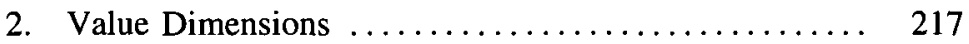

3. Cognitive Styles ..................... 220

4. Measuring Cultural Distance $\ldots \ldots \ldots \ldots \ldots \ldots \ldots \ldots 221$

C. Implications ......................... 223

1. Accounting Standards and Practices ........... 225

2. Legal Rules and Infrastructure .............. 229

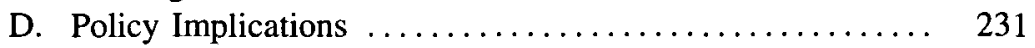

III. Informational Distance Revisited ................ 233

A. International Information Asymmetry ........... 233

B. Dominant Markets and Informed Trading ......... 236

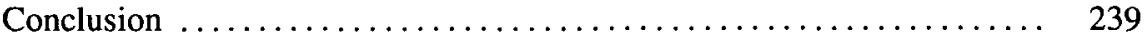

* Interdisciplinary Center Herzliya, Israel. For helpful comments on earlier versions of this paper I wish to thank Steven Choi, Hwa-Jin Kim, Kon Sik Kim, Jordan Siegel, and participants of the Conference on Cross-Listing of Emerging Market Companies, Stanford Law School. Errors remain my own. 
"Even Confucian managers respond to incentives."1

\section{INTRODUCTION}

This article considers the extent to which countries or companies can successfully borrow foreign corporate governance elements to improve their own corporate governance system. At the national level, such borrowing-often referred to as "transplantation"-requires public action by law-makers or regulators. The history of legal transplantation is long and checkered, beginning with the "law and development" movement of the 1960s. Often done at the behest of Western donor countries, direct transplantation efforts were largely futile in generating Western-like economic growth and have caused considerable political strife. The demise of communist regimes in Europe turned the region into a laboratory for legal reforms with the aim of establishing market economies. Generally inspired by North American notions of corporate governance, legal reforms during the 1990s were expected to provide investors with a hospitable and protective environment. ${ }^{2}$ With few exceptions, these reforms produced outcomes varying from disappointing to ruinous (as in Russia and the Czech Republic). ${ }^{3}$

Corporate governance reform is popular nonetheless. Studies conducted since the mid-1990s show that simple metrics of corporate governance quality correlate positively with important economic factors at both the national level and firm level. ${ }^{4}$ This evidence suggests, at least by implication that improving the quality of corporate governance would bring about concomitant benefits for nations and firms alike. Poor corporate governance was pointed to as one of the factors that could lead to economic crises like the 1997 financial crisis in Asia. Policy documents endorsed by major international bodies now advance codes of optimal corporate governance principles to be implemented by governments

1. Bernard S. Black, Corporate Governance in Korea at the Millennium: Enhancing International Competitiveness, 26 Iowa J. CoRP. L. 537, 545 (2001).

2. A prominent example for a reform blue-print that drew on American insights on corporate governance but did not rely directly on American legal sources is the code that was designed for Russia. See Bernard Black \& Reinier Kraakman, A Self-Enforcing Model of Corporate Law, 109 Harv. L. Rev. 1911 (1996).

3. Bernard Black, Reinier Kraakman \& Anna Tarassova, Russian Privatization and Corporate Governance: What Went Wrong?, 52 StAN. L. Rev. 1739 (2000); Merritt B. Fox \& Michael A. Heller, Corporate Governance Lessons from Russian Enterprise Fiascoes, 75 N.Y.U. L. Rev. 1720 (2000); Edward Glaeser, Simon Johnson \& Andrei Shleifer, Coase versus the Coasians, 116 Q. J. ECoN. 853 (2001); D.V. Vasilyev, Corporate Governance in Russia: Is There any Chance for Improvement? (2001), available at http://www.imf.org/external/pubs/ft/seminar/2000/invest/pdf/ vasil2.pdf.

4. There are now numerous studies in this branch of the literature. See, e.g., Rafael La Porta et al., Law and Finance, 106 J. Pol. Econ. 1113 (1998); Rafael La Porta et al, Legal Determinants of External Finance, 52 J. Fin. 1131 (1997); Rafael La Porta et al., Agency Problems and Dividend Policies Around the World, 55 J. Fin. 1 (2000); Ross Levine, Law, Finance, and Economic Growth, 8 J. Fin. Intermediation 36 (1999); Ross Levine, The Legal Environment, Banks, and Long-Run Economic Growth, 30 J. Money, CREDrt \& BANK. 596 (1998); Asli Demirguc-Kunt \& Vojislav Maksimovic, Law, Finance, and Firm Growth, 53 J. Fin. 2107 (1998). 
around the world. ${ }^{5}$ Corporate governance ratings prepared by private agencies encourage companies to adopt measures that the agencies consider desirable. ${ }^{6}$ These templates for desirable corporate governance invariably draw on AngloAmerican elements.

An alternative to corporate governance improvement through public action is improvement through private action by particular corporations. Such selfimprovement by private issuers faces serious obstacles, however. For instance, financial market players may consider the adoption of more investor-protective bylaws as a non-credible commitment by the issuer's insiders. This may be the case if the issuer's general national laws, regulatory agencies, and courts do not give full effect to such bylaws. To overcome this problem, issuers can engage in governance-improving private action by listing their securities on a foreign market-say, the U.S. market-whose governance system they consider superior. ${ }^{7}$ The idea that foreign firms actually engage in cross-listing to improve their corporate governance is often attributed to Jack Coffee. ${ }^{8}$ Bernard Black generalized this insight in several dimensions and coined the metaphor "piggybacking" to describe such renting of a country's corporate governance system by foreign corporations. ${ }^{9}$ In this view, cross-listing on a foreign stock market can serve as a bonding mechanism for corporate insiders to credibly commit to a better governance regime. Cross-listing could thus become a vehicle for international convergence toward globally desirable governance regimes.

The relations between cross-listing and corporate governance raise two separate but related questions. The first question may be dubbed "bonding or avoiding?" and reflects the idea that in terms of corporate governance, crosslisting may fail to engender the putative benefits suggested by the cross-listingas-bonding hypothesis. In contrast to the bonding hypothesis, an "avoiding hypothesis" proposes that stringent corporate governance requirements in destina-

5. The central document of this nature, on which many other documents draw, is AD HoC Task Force on Corporate Governance, OECD Principles of Corporate Governance, Doc. SG/CG(99)5 3 (1999); see also The World Bank, Corporate Governance: A Framework for IMPLEMENTATION (2001).

6. There are now several such rating services. For a discussion and empirical analysis based on data from Credit Lyonnais Securities Asia, see Krishna Palepu, Tarun KhanNa \& Joseph Kogan, Globalization and Similarities in Corporate Governance: A Cross-Country AnalYsis (Harvard University Strategy Unit, Working Paper No. 02-041, 2002).

7. The Enron/Arthur Andersen debacle and the ensuing waves of scandal have tarnished the reputation of the American market, but probably have not eroded it completely. See Edmund L. Andrews, U.S. Business Dim as Model for Foreigners, N.Y. TIMES, June 27, 2002 ("People around the world who for decades have looked to the United States as the model for openness and accountability in business have been sorely disillusioned by the mounting waves of scandal."). Yet even today, many would argue that in a global comparison, American securities markets provide public investors with a more hospitable and protective environment than most other markets around the world.

8. John C. Coffee, The Future as History: The Prospects for Global Convergence in Corporate Governance and its Implications, 93 Nw. U. L. REv. 641 (1999). For an earlier, more general analysis, see Amir N. Licht, Regulatory Arbitrage for Real: International Securities Regulation in a World of Interacting Securities Markets, 38 VA. J. INT'L L. 563 (1998).

9. Bernard S. Black, The Legal and Institutional Preconditions for Strong Securities Markets, 48 UCLA L. Rev. 781, 816 (2001); see also Bernard S. Black, The Core Institutions that Support Strong Securities Markets, 55 Bus. LAw. 1565 (2000) (an abridged version). 
tion markets actually deter insiders and may drive them to avoid cross-listing on these markets. I dealt with this issue on several occasions and argued that the avoiding hypothesis is better supported by empirical evidence. ${ }^{10}$

The bulk of this article is dedicated to analyzing the second question, which may be called "can bonding stick?" When properly considered, this inquiry goes to the root of comparative legal analysis and the design of legal reform based on foreign sources. In the present context, the question is whether foreign legal elements can be neatly "plugged-in" to an existing corporate governance system, be compatible with it, and produce the expected improvements. Such plugging-in of foreign legal elements can be achieved either through public or private action. Public action would include legislative or regulatory reform whereas private action would entail cross-listing on a foreign, better-governed market. This article argues that in considering the prospects of such steps one must assess the difference, or distance, between the source and target systems. ${ }^{11}$ A crucial factor appears to be the "cultural distance" between the two systems.

Arguments about cultural uniqueness of people, companies, or nations run the risk of sounding like hollow clichés. Worse yet, such arguments could be raised by interested rent-seeking parties such as managers and bureaucrats to thwart reform in governance institutions. To avoid this trap, this article draws on research from several disciplines. While the core problem is legal and economic in nature, other fields are also relevant-particularly, psychology and accounting. Securities laws mandate disclosure principles for public issuers, but the larger share of the content of disclosure is determined by accounting standards and practices. These disclosure duties are carried out by professionals in companies' home countries. I turn to different branches of psychology to give concrete content to the intuitive notions of cultural distance and corporations' foreignness. Recent advances in this field provide a framework for rigorously analyzing international differences in values and cognitive styles. Evidence surveyed in this article indicates that people from divergent cultures exhibit difference in their perception and judgment-a finding that bears directly on corporate governance. Among other things, it is now well-established that the functioning of national accounting and auditing systems is affected by cultural factors.

While the arguments put forward in this article are general, the present analysis focuses on South Korea as the central reference case. Korean corporations tend to be organized in conglomerates called chaebol, which commentators often associate with Korea's Confucian heritage. Korea belongs to a group of

10. See Amir N. Licht, Genie in a Bottle? Assessing Managerial Opportunism in International Securities Transactions, 2000 Colum. Bus. L. Rev. 51 (2000) [hereinafter Genie in a Bottle]; Amir N. Licht, Managerial Opportunism and Foreign Listing: Some Direct Evidence, 22 U. PA J. INT'L ECON. L. 325 (2001) [hereinafter Managerial Opportunism]; Amir N. Licht, Cross-Listing and Corporate Governance: Bonding or Avoiding?, 4 CHI. J. INT'L L. 141 (2003) [hereinafter Bonding or Avoiding].

11. As a dichotomous question-namely, whether the reform will create any change in the target system-the question is uninteresting. Surely, any non-negligible step will produce some change. The challenge lies in assessing gradual and relative differences and their impact. 
Asian countries with a Confucian heritage distinctly different from the Western cultural heritage. The issue of Confucian values has been a constant theme in comparative corporate governance analyses for over a decade, but the effect of these values has not been satisfactorily discerned. ${ }^{12}$ More generally, Korea is a prime example of economic development, having grown from a poor country in the early 1960s to one of today's leading economies. In the wake of the 1997 Asian financial crisis, Korea adopted North American corporate governance features to embark on a path of legal and institutional reform. In addition, the Korean government in 2002 took steps to encourage cross-listing of Korean corporations on several foreign markets. ${ }^{13}$ Therefore, the Korean case provides us an opportunity to analyze efforts toward corporate governance improvement through both public and private action. Among English-language materials, scant attention has been paid to the effect of Korea's culture on the implementation of the legal reforms or the recent cross-listing initiative. ${ }^{14}$ Preliminary evidence from the short period following the reforms suggests, however, that many of them remain on paper only, because of cultural factors. This article notes that these reforms may reflect a graver problem. Implementing foreign governance mechanisms incidentally reflects an attempt to write off Korea's Confucian heritage as an asset for governance institutions. Korea's cultural heritage should not be perceived solely as an archaic legacy of past generations. Rather, this cultural endowment should be regarded as part of the country's social capital, capable of modern, productive use.

Finally, the article returns to cross-listed firms and argues that a country's foreign character retains its dominance in under-appreciated ways. While crosslisting might erode some of these firms' national features, it cannot eliminate them. Adding a layer of North American rules cannot remedy deeply-rooted deficiencies in firms' governance. Companies and their management that crosslist in the United States do not become American by this transaction. In addition to affecting the firm itself, cross-listing also affects the markets on which the firm is listed. Specifically, foreign firms' home markets tend to dominate the price formation processes of their securities. This dominance by the foreign firms' home market is also related to cultural distance through its effect on informational asymmetries. Cross-listing can thus externalize undesirable effects to the host market, particularly in the form of insider trading.

Part I begins with a brief review of the relations between cross-listing and corporate governance as reflected in the bonding-or-avoiding debate. It then points to recent empirical evidence suggesting the importance of cultural distance in cross-listing patterns around the world. Part II begins with some background on Korean corporate governance. Next, this Part elucidates the notions of firms' foreignness and cultural distance and demonstrates how these concepts

12. The large majority of such analyses have dealt with Japan, the prominent Asian economy in the late 1980s.

13. Companies Allowed to List Stocks Directly on Nine Foreign Bourses, The Korea HerALD, Feb. 6, 2002. See infra note 89.

14. See infra note 100. 
can illuminate corporate governance problems in Korea. Part III focuses on the dominance of home country securities markets in price formation processes of cross-listed stocks.

I. Understanding CROSS-Listing

\section{A. Financial and Business Aspects}

Cross-listing transactions ${ }^{15}$ have attracted the attention of finance scholars for over twenty-five years. ${ }^{16}$ Interest in cross-listing has been on the rise since the mid-1980s, paralleling the growing number of foreign issuers listed on American markets. ${ }^{17}$ Scholars have advanced several independent theories regarding what motivates companies to cross-list their shares on foreign markets. A certain evolution is identifiable in these theories and the studies that purported to test them. These theories were first about financial motivations for crosslisting and then, beginning in the early 1990 s, studies about other business motivations for cross-listing also emerged. For present purposes, brief mention of these theories will suffice. ${ }^{18}$

15. Two notes about terminology: First, this article usually uses "cross-listing" to describe the relevant transaction but the literature also interchangeably refers to dual listing, multiple listing, and foreign listing. While I prefer the latter term, which is the most accurate and general, "cross-listing" is the more commonly used term today. Second, unless the context indicates otherwise, references to stocks or shares in the text also refer to other corporate securities.

16. The pioneering work in the finance literature is Robert C. Stapleton \& Marti G. Subrahmaniam, Market Imperfections, Capital Market Equilibrium and Corporate Finance, 32 J. FIN. 307 (1977). Subsequent seminal studies include Rene Stulz, A Model of International Asset Pricing, 9 J. FIN. ECON. 358 (1981); Vihang R. Errunza \& Etienne Losq, International Asset Pricing under Mild Segmentation: Theory and Test, 40 J. Fin. 105 (1985); Gordon J. Alexander, Cheol S. Eun \& S. Janakirmanan, International Listings and Stock Returns: Some Empirical Evidence, 23 J. Fin. \& Quantitative ANAL. 135 (1988). However, listing stocks on foreign markets-namely, markets other than the issuer's country of nationality -is a much older phenomenon. Canadian railway firms were listed on the New York Stock Exchange (NYSE) and the London Stock Exchange (LSE) as of the 1910s. Toward the end of the 1980s, major firms from the three major industrial blocs (the United States, Europe, and Japan) became cross-listed on several exchanges in these regions. See Licht, supra note 8 , at 564 . Since the early 1990 s, the number of foreign firms listed on the markets of developed countries ranged between $5-15 \%$ of the total number of listed issuers. For updated statistics on foreign listing, see the website of the World Federation of Exchanges, at http:// www.world-exchanges.org.

17. The common way for issuers to list on a foreign stock exchange, or just create a foreign market presence without listing, is by using a depositary receipt (DR) facility. DRs include American Depositary Receipts (ADRs), Global Depositary Receipts (GDRs), and New York Shares (NYSs). These are negotiable U.S. securities that generally represent a non-U.S. company's publicly traded equity. There are also Euro DRs (EDRs). Although typically denominated in U.S. dollars, depositary receipts can also be denominated in Euros. Currently, there are over 2,000 depositary receipt programs in the United States for companies from over 70 countries. See the Bank of New York's guide on depositary receipts, available at http://www.adrbny.com/dr_basics_and_benefits. jsp. For an overview of legal aspects, see Mark A. Saunders, American Depositary Receipts: An Introduction to U.S. Capital Markets for Foreign Companies, 17 Fordham INT'L L.J. 48 (1993).

18. For further detail, see Licht, Genie in a Bottle, supra note 10, on which this subsection draws. See also G. Andrew Karolyi, Why Do Companies List Abroad? A Survey of the Evidence and Its Managerial Implications, 7 N.Y.U. Salomon Brothers Center Monograph No. 1 (1998). 


\section{Segmentation and Diversification Gains}

Cross-listings were first thought of as a means to lower firms' cost of capital by enabling the firm to get more money from investors when offering its stock to the public. ${ }^{19}$ This effect could stem from two related sources: diversification gains and segmentation gains. Internationally diversified portfolios minimize the investor's exposure only to the global systematic risk. ${ }^{20}$ Segmentation occurs where similar assets in different markets have different prices, barring transaction costs. The popularity of investing in emerging market stocks largely stems from potential segmentation gains. Such markets often exhibit barriers to foreign investment due to regulatory limits on foreign holdings in domestic corporations, informational barriers, and so forth. Cross-listing brings foreign stocks closer to investors, in addition to several other advantages arising from lower transaction costs.

\section{Liquidity}

Cross-listing may contribute to share value by increasing stock liquidity, as measured by the bid-ask spread. Narrower spreads following a cross-listing would indicate improved liquidity, which increases share value. ${ }^{21}$ Cross-listing may result in enhanced inter-market competition that works to lower the spread and may improve liquidity. However, multi-market trading might decrease liquidity by fragmenting order flows among the markets. The net result depends on the circumstances of each security. ${ }^{22}$

19. For a summary, see Rene M. Stulz, Globalization of Corporate Finance and the Cost of Capital, 8 J. Applied CORP. FIN. 30 (1999). An alternative, more technical way, to present this idea is to consider cross-listing as a means for lowering the expected return on capital. When a firm has to promise would-be investors a higher return on their capital contribution per share, the firm and its entrepreneurs affectively get equity capital at a higher cost. Higher stock values are therefore associated with lower expected returns, from the firm's perspective.

20. At the domestic economy level, a firm's return has a unique risk component stemming from its specific characteristics and business. This non-systematic risk can be "diversified away" relatively easily by investing in a number of firms engaged in different businesses. Even a little diversification, such as investment in a handful of randomly chosen stocks, can provide a substantial reduction in risk. The other type of risk, systematic risk, is unavoidable; that is, it is undiversifiable at the domestic level because systematic risk stems from economy-wide perils that threaten all businesses. International investment takes diversification one step further. For a review, see Vihang Errunza et al., Can the Gains from International Diversification be Achieved without Trading Abroad?, 54 J. FIN. 2075 (1999); K. Geert Rouwenhorst, European Equity Markets and EMU, 55 Fin. ANAlysts J. 57 (1999).

21. Improved liquidity means mainly that an investor can trade the security with lower premium (the bid-ask spread) and lower market price impact. See Yakov Amihud \& Haim Mendelson, Asset Pricing and the Bid-Ask Spread, 17 J. FIN. Econ. 223 (1986). At the domestic level, evidence shows that corporate listing decisions are consistent with the objective of increasing liquidity. See Yakov Amihud \& Haim Mendelson, Liquidity and Asset Prices: Financial Management Implications, 17 Fin. MGMt. 5 (1988).

22. See K.C. Chan et al., Information, Trading and Stock Returns: Lessons from Dually-Listed Securities, 20 J. BANKING \& FIN. 1161 (1996). 


\section{Increased Shareholder Base}

By cross-listing its stocks, a firm could expand its potential investor base more easily than if it traded on a single market. Cross-listing brings foreign securities closer to potential investors and increases their awareness of investment opportunities, which could lower expected returns. ${ }^{23}$ In business management terminology this aspect is called "firm visibility"-a broad notion encompassing frequent mention of the firm in the financial press and closer monitoring of its securities by analysts.

\section{Visibility and Marketing}

The putative benefits of increased visibility in the host country exceed the anticipated benefits of shareholder base increase. In addition to greater demand for its stock, listing a corporation's stock abroad provides the company with greater access to foreign product markets and facilitates selling debt in the foreign country. ${ }^{24}$ A company becomes more credible by providing information to the local capital market because the continuous flow of information allows the capital market to make quicker and more accurate decisions. ${ }^{25}$

\section{Technical Issues}

Even where feasible, effecting a securities transaction abroad is still more complicated and expensive than doing so domestically. Cross-listing can improve a firm's ability to engage in structural transactions abroad such as foreign mergers and acquisitions, stock swaps, and tender offers. ${ }^{26}$ Moreover, crosslisting also facilitates and enhances the attractiveness of employee stock ownership plans (ESOPs) of large multinational corporations. Local listing in the foreign market provides foreign employees with an accessible exit mechanism for their stocks.

\section{B. Corporate Governance}

The notion that issuers may want to improve their corporate governance by subjecting themselves to a better regulatory regime through cross-listing is appealingly elegant. Yet it was only in the late 1990s that theories about legal and governance implications of cross-listing were first articulated in detail. An early article by this author puts forth a general model of the interaction between legal

23. See Robert Merton, Presidential Address: A Simple Model of Capital Market Equilibrium with Incomplete Information, 42 J. Fin. 483 (1987).

24. See Kent H. Baker, Why U.S. Companies List on the London, Frankfurt, and Tokyo Stock Exchanges, 6 J. INT'L SEC. MARKETS 219, 221 (1992).

25. See Edward B. Rock, Greenhorns, Yankees, and Cosmopolitans: Venture Capital, IPOs, Foreign Firms, and U.S. Markets, 2 TheoretiCAL INQuIRIEs L. 711 (2001) (discussing foreign listing by Israeli firms); Edward B. Rock, Coming to America? Venture Capital, Corporate IDENTITY ANd U.S. Securtties Law (University of Pennsylvania Institute for Law \& Economics, Research Paper 02-07, 2002).

26. See G. Andrew Karolyi, Daimler Chrysler AG, The First Truly Global Share, 9 J. CoRP. Fin. 409 (2003). 
regimes following a cross-listing. ${ }^{27}$ By cross-listing the issuer may opt into another securities regulation regime but does not sever legal ties to its home country. The outcome is a rather complex legal regime in which some components may bring about an improvement in the composite regime governing the issuer but others may erode its effectiveness. There is no reason to assume a priori that cross-listing would entail an improvement in issuers' corporate governance. Inferior legal provisions in the host market may have a dominant effect on the issuer.

In an oft-cited article, Jack Coffee sets forth an argument known as the "bonding hypothesis." Coffee argues that foreign firms actually use a listing on an American market to bond their insiders to better governance standards:

Large firms can choose the stock exchange or exchanges on which they are listed, and in so doing can opt into governance systems, disclosure standards, and accounting rules that may be more rigorous than those required or prevailing in their jurisdiction of incorporation ... [T] he most visible contemporary form of migration seems motivated by the opposite impulse: namely, to opt into higher regulatory or disclosure standards and thus to implement a form of "bonding" under which firms commit to governance standards more exacting than that of their home countries. ${ }^{28}$

Coffee further proposes that as foreign issuers migrate to list in U.S. markets and become subject to its standards, the relative importance of variations among the corporate laws of different countries should decline. Moreover, "the application of U.S. securities law, or some 'harmonized' model largely based on it, would instead impose transparency and significantly constrain opportunism by controlling shareholders." 29 Accordingly, markets in countries whose laws provide better protection to minority shareholders, such as the United States and the United Kingdom, will attract firms with dispersed ownership, while markets in low-corporate governance countries will trade shares of firms with concentrated ownership. ${ }^{30}$ Edward Rock identifies the structure of the American secur-

27. See Licht, supra note 8 , at 617-21.

28. Coffee, supra note 8, at 651-52. The idea of using stock exchange listing as a mechanism for bonding to a different, arguably better, governance regime first appeared in a fully domestic context in the United States. See Jeffrey N. Gordon, Ties that Bond: Dual Class Common Stock and the Problem of Shareholder Choice, 76 CAL. L. REv. 3, 9, 66-68 (1988) ("insiders who seek to lower the cost of capital will find it valuable to bond a promise that the firm's single class capital structure will not be renegotiated . . . . the NYSE [one-share-one-vote listing] rule is the only secure bond available for such a promise."). Later developments in the saga of the one-share-one-vote rule have proven, however, that stock exchanges' bonding function is rather flimsy. America's national markets failed to live up to the challenge of preferring investor-protecting rules to management-friendly ones. This story has been recounted several times in the legal literature, but most of the accounts appeared before the crisis was fully resolved. These developments are discussed in Edward B. Rock, Securities Regulation as Lobster Trap: A Credible Commitment Theory of Mandatory Disclosure, 23 CARDozo L. Rev. 675, 698-700 (2002).

29. Coffee, supra note 8 , at 652 .

30. Id. It is not quite clear why Coffee mentions U.K. markets together with U.S. markets as potential vehicles for piggybacking. Cross-listing on the London Stock Exchange does not involve material changes in disclosure duties on behalf of the issuer or its management. Moreover, even the theoretical threat of class litigation which exists in the United States does not apply in the United Kingdom, in which class actions are underdeveloped. As a result, neither substantive law nor enforcement mechanisms are likely to engender corporate governance improvements. 
ities regulation regime as a potential bonding mechanism. Rock argues that it has a characteristic "lobster trap" structure: easy to enter voluntarily but hard to exit. These features are necessary if disclosure regulation is to aid issuers in making a serious commitment to complete and continuous future disclosure. ${ }^{31}$

Recently, Coffee modified his theory in light of international stock market developments and empirical research. ${ }^{32}$ This version also envisions the possibility of a dual-equilibrium global environment, in which "high disclosure" exchanges would serve as regional "super-markets," providing bonding services to high-quality issuers. However, firms less interested in attracting minority investors, but still desiring some degree of liquidity, might trade only on lower-disclosure exchanges. ${ }^{33}$ The crucial question is what mechanism could support the high disclosure, race-for-the-top equilibrium? Again, the theoretical answer is market liquidity. Uninformed public investors would flock to markets where they are better protected, leading to large liquidity pools.

Theoretical and empirical research on cross-listing concentrates on firms and stock exchanges as the actors that interact in the global market for crosslistings. Such research analyses are misleadingly partial. The key weakness in the basic bonding theory is that it links the interests of issuers with those of insiders in decision-making positions, including managers and controlling shareholders, and hence underestimates the potential for insiders' opportunism. In particular, little attention has been paid to the possible role of managerial opportunism in company decisions regarding whether to cross-list and on which destination markets. More recent analyses, however, better address this issue. ${ }^{34}$

The central insight here is that agents make corporate decisions with regard to cross-listing. Agency theories imply that such agents do not behave altruistically for the benefit of the corporation or its shareholders. Company insiders in decision-making positions cannot be expected to remain agnostic to legal duties pertaining to them individually. ${ }^{35}$ Examples of such issues include regulation of self-dealing and affiliated party transactions, disclosure of top executive remuneration on an individual basis, ${ }^{36}$ and opportunities to engage in insider trading with impunity.

31. Rock, supra note 28 , at $686-90$.

32. John C. Coffee, Racing Towards the Top?: The Impact of Cross-Listings and Stock Market Competition on International Corporate Governance, 102 CoLuM. L. Rev. 1757 (2002).

33. Id. at 1816.

34. See Steven Huddart, John Hughes \& Markus Brunnermeier, Disclosure Requirements and Stock Exchange Listing Choice in an International Context, 26 J. ACCT. \& ECON. 237 (1999); OREN Fuerst, A Theoretical analysis of the Investor Protection Regulations Argument for Global Listing of Stocks 3 (Int'l Center for Fin. at Yale, Working Paper, 1998), available at http://papers.ssrn.com/sol3/papers.cfm?/abstract_id=139599; Stulz, supra note 19; THOMAS J. CHEMmanur \& Paolo Fulghieri, Choosing an Exchange to List Equity: A Theory of Dual Listing, Listing Requirements, and Competition Among Exchanges (Working Paper, 2001); see also Carmine DiNoia, Competition and Integration Among Stock Exchanges in Europe: Network Effects, Implicit Mergers and Remote Access, 7 European Fin. MGMt. 39 (2001).

35. Licht, Genie in a Bottle, supra note 10, at 88-97.

36. A special aspect of this issue that came to the forefront during the 2002 corporate governance scandal in the United States is the disclosure of top executive stock option plans. See Lucian Arye Bebchuk, Jesse M. Fried \& David I. Walker, Managerial Power and Rent Extraction in the 
Insiders have incentives to prefer their own self-interest over the interest of their company when deciding to cross-list. Even assuming mangers have substantial holding of their company's stock and options and enjoy the increase in firm value, the benefits from cross-listing inure to the entire class of shareholders, creditors, etc., while the costs are borne entirely by the insiders. Put differently, insiders alone lose opportunities to derive private benefits from the corporation, while the entire corporate entity enjoys the value increase consequent to this loss. ${ }^{37}$

The upshot of this reasoning is that cross-listing and bonding may not overlap. When the foreign market effectively imposes better corporate governance on foreign issuers, managers may choose to cross-list their firm in this market to exploit the financial and other business benefits of such a transaction, while foregoing expected private benefits. In other cases, cross-listing may not entail corporate governance improvements. Indeed, cross-listing could then be used to avoid a more stringent regime; piggybacking may lead to a race for the bottom.

Whether issuers seek or avoid markets that offer better governance regimes is debatable. But to empirically resolve this question raises considerable challenges. Many different motivations may affect the cross-listing decision and make it difficult to discern the precise effect of each motivation. Researchers have employed different methodologies for investigating cross-listing, often posing research questions that were not sensitive to the issue. A sober analysis, especially of recent unpublished studies, indicates that the bonding hypothesis does not receive support from the extant empirical evidence while the avoiding hypothesis does. Evidence also supports the managerial opportunism hypothesis. ${ }^{38}$

When surveyed, managers and other decision-makers of actual and wouldbe cross-listed corporations all around the world cite business issues, primarily increased visibility in the destination market, as the dominant reason for effecting a cross-listing. When asked about factors that militate against cross-listing, respondents unanimously cite increased disclosure requirements as the most serious obstacle. ${ }^{39}$ Studies that investigate regularities in firms' choice of destination markets ("migration studies") offer consistent results. Firms were more

Design of Executive Compensation, 69 U. CHI. L. REv. 751 (2002) (surveying theory and evidence and arguing that managerial opportunism is a major factor in such plans).

37. This logic was generalized with the concept of "significantly redistributive issues" by Lucian A. Bebchuk, Federalism and the Corporation: The Desirable Limits on State Competition in Corporate Law, 105 HARv. L. Rev. 1437, 1461-67 (1992).

38. For a comprehensive critical survey, see Licht, Bonding or Avoiding, supra note 10.

39. See James A. Fanto \& Roberta S. Karmel, A Report on the Attitudes of Foreign Companies Regarding a U.S. Listing, 3 STAN. J. L. BUs. \& Fin. 51 (1997). See also Usha R. Mittoo, Managerial Perceptions of the Net Benefits of Foreign Listing: Canadian Evidence, 4 J. INT'L FIN. MGMT. Acct. 40 (1992) (noting a similar finding for Canadian firms listed on U.S. or U.K. markets); KaRL LINS, Deon Strickland \& Marc Zenner, Do Non-U.S. Firms Issue Stock on U.S. Equity Markets to Relax Captral Constraints? (University of North Carolina, Working Paper, 2000); Franck Bancel \& Usha R. Mittoo, European Managerial Perceptions of the Net Benefits of Foreign Stock Listings, 7 Eur. Fin. Mgmt. 213 (2001); Nobuyoshi Yamori \& Taui Baba, Japanese Management Views on Overseas Exchange Listings: Survey Resulrs (Center for Pacific Basin Monetary and Economic Studies, Working Paper PB99-05, 1999); Robert Brunner, Susan Chaplinsky 
likely to cross-list on stock exchanges with lower disclosure levels and in countries that represent larger markets for the firms' products or where their peers were listed. This finding is in line with the visibility rationale, which proposes that firms seek greater public exposure in the destination market. ${ }^{40}$ Recent studies that have taken novel empirical approaches to isolating the effects of managerial interests suggest that insiders may take advantage of cross-listings to derive private benefits. ${ }^{41}$

\section{Informational and Cultural Distance}

Important as it may be for policy-makers, the bonding-or-avoiding debate does not exhaust the richness of cross-listing as a legally-relevant phenomenon. Whether firms are driven by bonding or by avoiding motivations is ultimately an empirical question. The two competing hypotheses are not mutually exclusive in theory. Although the majority of issuers apparently behave according to the avoiding theory, some issuers may want to take advantage of destination-markets' stringent regulatory regimes, in line with the bonding theory. This begs a question not yet fully explored in the legal and finance literature: Can they do this? Both the bonding and the avoiding hypotheses share an implicit assumption that the regulatory regime in the destination market, regardless of its content, would apply with equal effectiveness as compared to the home-market regime. Under the bonding hypothesis, the bonding "sticks" to the effect of improving firms' corporate governance. Under the avoiding hypothesis, the bonding would stick and is therefore being avoided.

\& Latha Ramchand, Coming to America: A Clinical Study of Ipos in the U.S. by Foreign FIRMS (Working Paper, 1999).

40. See Marco Pagano, Ailsa A. Roell \& Josef Zechner, The Geography of Equity Listing: Why Do Companies List Abroad?, 57 J. Fin. 2651 (2002); Marco Pagano, Otto Randl, Ailsa A. Roell \& Josef Zechner, What Makes Stock Exchanges Succeed? Evidence from Cross-Listing Decisions, 45 Eur. Econ. Rev. 770 (2001) [hereinafter Stock Exchange Success]. For early pioneering works in this line see Shahrokh M. Saudagaran \& Gary C. Biddle, Foreign Listing Location: A Study of MNCs and Stock Exchanges in Eight Countries, 26 J. INT'L Bus. STud. 319 (1995); Shahrokh M. Saudagaran \& Gary C. Biddle, Financial Disclosure Levels and Foreign Stock Exchange Listing Decisions, 4 J. INT'L. Fin. MGmt. \& Acc. 106 (1992); Gary C. Biddle \& Shahrokh M. Saudagaran, Foreign Stock Listings: Benefits, Costs, and the Accounting Policy Dilemma, 5 Acct. Horizons 69 (1991); Gary C. Biddle \& Shahrokh M. Saudagaran, The Effects of International Disclosure Levels on Firms' Choices among Alternative Foreign Stock Exchange Listings, 1 J. INT'L. MGMr. \& Acct. 55 (1989); Shahrokh M. Saudagaran, An Empirical Study of Selected Factors Influencing the Decision to List on Foreign Exchanges, 19 J. INT'L BuS. STUD. 101 (1988).

41. See Jordan I. Siegel, Can Foreign Firms Bond Themselves Effectively By Renting U.S. Securities Laws?, J. Fin. Econ. (forthcoming 2004); Annalisa Russino, Salvatore Cantale \& arturo Bris, Market Segmentation, Corporate Control, and Foreign Listing (Working Paper, 2001); Warren Bailey, G. Andrew Karolyi \& Carolina Salva, The Economic ConseQuences of Increased Disclosure: Evidence from International Cross-Listings (Working Paper, 2002); Nuno C. Martins, Asymmetry of Information in Emerging Markets: Should a Firm Issue Its Securities Locally or Abroad? (Working Paper, 2002). The study of William A. Reese, JR. \& Michael S. Weisbach, Protection of Minority Shareholder Interests, Cross-Listings in the United States, and Subsequent Equity Offerings (Working Paper, 2001), who argue for the bonding hypothesis, in my mind does not support their interpretation and in fact provides evidence to the contrary. See Licht, Bonding or Avoiding, supra note 10. 
Existing literature on corporate governance improvement through private action (cross-listing) reflects an assumption that legal transplantation is a relatively straightforward feat. As noted in the introduction, experience with corporate governance reform through public action (for example, legislative reforms) has shown otherwise. The simple fact that laws work well in certain countries does not ensure they will work well, if at all, in other countries. Similarly, there is no a priori support for the assumption that host-market regulations would effectively govern foreign issuers' affairs. The high diversity of corporate governance regimes around the world in fact suggests that some host-market systems would work better than others-that is, they would fit better.

Cross-listing transactions provide a rare opportunity to investigate the intuitive proposition that the "goodness of fit" among legal transplants varies across legal regimes in correlation with the proximity between them. Because there are scores of issuers who have made the decision whether and where to cross-list, it is possible to search for regularities in cross-listing patterns that may bear on this question. In what follows, I look into some recent empirical studies that present preliminary evidence in support of this proposition. These studies point to informational and cultural distance as the dominant factors in cross-listing patterns around the world.

Pagano, Randl, Roell, and Zechner investigate how the actual cross-listing choices of European companies correlate with specific features of exchanges and countries. ${ }^{42}$ Consistent with the visibility rationale for cross-listing, companies are found to be attracted to larger markets than their home exchanges and to markets on which other firms from the same industry are listed. Destination countries have on average lower accounting standards than origin countries, confirming the findings of other studies mentioned above. Notwithstanding their geographically limited sample, Pagano et al. are able to demonstrate that companies tend to list more frequently within groups of countries that are culturally similar. These researchers identify three groups of countries: one including Austria, Germany, the Netherlands, and Switzerland; another including Belgium, France, Italy, and Spain; and a third including Great Britain and the United States; Sweden is not assigned to any group. These groups are reminiscent of cultural regions identified in the work of Geert Hofstede: Germanic, (economically developed) Latin, Anglo, and Nordic. ${ }^{43}$

Using a nearly comprehensive data set of foreign listings in 1998, Sarkissian and Schill find strong evidence that host-home cross-listing activity clusters regionally. ${ }^{44}$ Geographic proximity and other variables of familiarity such as trade, common language, colonial ties, and similar industrial structure play an important role in the choice of overseas host market, more significant than fi-

42. Pagano et al., Stock Exchange Success, supra note 40 . The sample covered all the first cross-listing effected in 1986-97 by both financial and non-financial companies listed domestically in the main segment of the following ten exchanges: Amsterdam, Brussels, Frankfurt, London, Madrid, Milan, Paris, Stockholm, Vienna, and Zurich/Basel/Geneva.

43. See infra note 115 .

44. See Sergei Sarkissian \& Michael J. Schill, The Overseas listing Decision: New Evidence of Proximity Preference (Working Paper, 2001). 
nancial factors. ${ }^{45}$ The preference for familiar markets is particularly acute among firms outside the G-5 group of industrialized countries and among firms producing non-tradable goods. Firms from non-G-5 countries also tend to target overseas listings in equity markets, which are larger, more liquid, more highly capitalized, and are located in countries with higher scores on legality, meaning observance of the rule of law. ${ }^{46}$ The top host countries are the United States, United Kingdom, Germany, Switzerland, and Luxembourg. ${ }^{47}$

These emerging signs of the role played by cultural proximity in foreign listing are corroborated by research that yields similar results regarding crossborder portfolio investment. Portes and Rey ${ }^{48}$ show that cross-border equity transaction flows are explained by a "gravity model," 49 in which market size, efficiency of the transaction technology, and distance are the most important determinants. The significant negative role of geographical distance is puzzling at first glance, since, unlike goods, securities are "weightless." Portes and Rey surmise that geographical distance hinders economic exchanges due to cultural affinities that affect economic relations through their contribution to informational frictions. ${ }^{50}$ These results indicate that the geography of information and informational friction dominate other factors-including financial motivations-in the distribution of cross-border securities transactions. ${ }^{51}$

II.

\section{Understanding Cultural Distance}

A seminal finance model by Robert Merton, which underlies many crosslisting studies, derives its results from the premise that investors can invest only

45. Little support is found for the hypothesis that overseas listing firms are primarily motivated by diversification gains. Rather than maximizing the diversification gain by listing in markets with little economic correlation with one's home market, cross-listing activity is more common across markets for which return correlation is relatively high. Id. at 18.

46. The rule of law measure is based on the commonly-used index of the International Country Risk Guide (ICRG) that gauges the incidence of crime, enforceability of private and government contracts, and respect for property rights. The finding cited in the text is not surprising in light of the fact that the top host countries are also among the top scorers on the rule of law index.

47. Sarkissian and Schill argue that the stringency of disclosure requirements in a foreign country appears to attract foreign country listings, seemingly in contrast to findings by Saudagaran and Biddle, supra note 40, and Pagano et al., supra note 42. This contradiction could stem from the peculiar way in which Sarkissian and Schill gauge disclosure stringency. Unlike the former researchers, who use indices of disclosure requirements, the latter use a dummy variable that indicates whether the host country insists that the issuer use a different set of accounting standards than the set used in its home country. Although this yardstick does capture a sense of stringency in regulation, it does not reflect any improvement in the informativeness of the required disclosure system.

48. See Richard Portes \& Helene Rey, The Determinants of Cross-Border Equity Flows: The Geography of Information (University of California, Berkeley, Center for International Development \& Economic Research (CIDER), Working Paper C00-111, 2000).

49. A "gravity model" is commonly used for trade in goods. It explains trade between countries $\mathrm{i}$ and $\mathrm{j}$ by the masses (gross domestic products) and distance; more elaborate versions include cultural and other variables. Id. at 1 , n.l.

50. See James E. Rauch, Business and Social Networks in International Trade, $39 \mathrm{~J}$. Econ. LrT. 1177 (2001).

51. Portes and Rey's results should be read in light of a large literature that documents a strong home bias in international investment. See infra pp. 58-61. 
in firms of which they know. ${ }^{52}$ The foregoing discussion suggests that Merton's model now has an augmented version. Investors not only buy securities of firms which they know; they prefer securities of firms which they know better. This phenomenon is broader than the well-known home bias. ${ }^{53}$ The types of familiarity that affect cross-listing and cross-border trading relate to geographical proximity, common historical heritage, and cultural proximity.

The evidence surveyed in the prior discussion demonstrates that foreignness is not a dichotomous trait. Rather, for a particular destination market, such as the NYSE, certain issuers may be "more foreign" than others. The degree of foreignness depends on a number of factors beyond nationality. Geographical proximity and historical heritage, which may include legal transplantation by colonial rulers, are straightforward concepts that do not need much elaboration. In comparison, cultural proximity is more elusive. Culture is a rich concept with many alternative definitions. This section explores the ways in which "cultural distance" between countries can be explicated and related to corporate governance, beyond just pointing out idiosyncratic features but without resorting to detailed descriptions. ${ }^{54}$ Korean notions of Confucian corporate governance provide the basic reference case in this article. Specifically, the focus is on the possibility of enhancing Korean corporate governance with North Americaninspired elements through either cross-listing or direct legal reform.

\section{A. Context: Korean Corporate Governance}

\section{A Brief Economic History}

Korea's modern economic history begins in $1960 . .^{55}$ After the rise of General Park Chung Hee to power in 1961, the Korean government opted for centralized economic planning. Having forced prominent businesspeople to turn in their equity shares in banks to the state, the government was also in control of commercial banks. Nationalistic sentiments and private firms' lack of reputation led the government to reject foreign direct investment (FDI) for financing enterprises that would come under foreign control. Instead, the government relied on foreign loans guaranteed by state-owned banks. In parallel, the government also used a variety of measures to prefer certain firms to others and direct them to specific industries. The debt-equity ratio of firms soared to over 300 percent in the 1970s. In 1972, the government had to bail out the debt-burdened corporate sector, thus violating creditors' rights and aggravating moral hazard. Another round of directed financial support to select firms ensued and gave rise to the swelling of the chaebols to mammoth sizes: the chaebol is a group of

52. Merton, supra note 23.

53. See infra pp. 58-61.

54. This is the method anthropologists tend to prefer. See Clifford Geertz, The InTERPRetation of Cultures: Selected Essays 26-28 (1973) (advocating the study of cultures through "thick description").

55. The following draws on Byung-Nak Song, The Rise Of The Korean Economy ch. 3 (2nd ed. 1997); Phillip Wonhyuk Lim, The Evolution Of Korea's Development Paradigm: Old Legacies and Emerging Trends in the Post-Crisis Era (ADB Institute, Working Paper 21, 2001). 
specialized companies with interrelated management servicing one another. From 1980 to 1997, this trend continued with few significant changes. Although the democratization of South Korea in 1987 brought an end to direct control of business, the strong emphasis on export, the rejection of FDI, and the implicit protection against bankruptcy continued. The government did not directly address problems of moral hazard and outright corruption. ${ }^{56}$

During the three decades preceding the 1997 financial crisis, the Korean economy grew from that of a poor developing country to one of the leading world economies. ${ }^{57}$ In 1996, Korea joined the prestigious OECD club of wealthy nations, after taking several measures to liberalize its capital markets. During the summer of 1997, Thailand was hit by a financial crisis that stemmed from foreign investors' loss of confidence. The crisis quickly spread to the entire East Asian region. Korea was severely hit by this crisis, but there is wide agreement that its structural problems existed well before the crisis hit. At that time, the debt-equity ratio of the top 30 chaebols, which dominated a huge portion of the economy, had reached 519 percent.

With its foreign-exchange reserves nearly depleted, Korea applied to the International Monetary Fund (IMF) in November 1997, for a U.S. $\$ 58$ billion bailout package. The Korea-IMF Memorandum on the Economic Program provided for a wide range of corrective measures related to macroeconomic policy, fiscal policy, and financial and corporate sector restructuring, with a strong emphasis on corporate governance reform. This was followed by subsequent memoranda, in line with the IMF's conditionality policy. ${ }^{58}$ However, the economy rebounded far more quickly than anticipated and by 2001 Korea had fully repaid its rescue loan.

\section{The Chaebol}

The hallmark of Korean corporate governance ${ }^{59}$ is the chaebol. This corporate structure was first introduced in Korea by the Japanese colonial

56. Lim, supra note 55, at 16 .

57. The following draws on Hal S. Scotr \& Philip A. Wellons, International Finance: Transactions, Policy, and Regulation ch. 21 (5th ed. 1998); Hwa-Jin Kim, Taking International Soft Law Seriously: Its Implications for Global Convergence in Corporate Governance, 1 J. KOREAN L. 1 (2001); HUN-JoO PARK, AFTER Dirigisme: Globalization, Democratization, and the Paternalistic State In Korea (Working Paper, 2000).

58. Under the conditionality policy, grant of foreign aid by the IMF is conditioned on the recipient country's taking corrective measures. For an historical review of this policy, see Balakrishnan Rajagopal, From Resistance to Renewal: The Third World, Social Movements, and the Expansion of International Institutions, 41 HARV. INT'L L.J. 529, 569-76 (2000).

59. Apparently, the term "corporate governance" does not have an equivalent in the Korean language. A series of symbols in Hangul representing "ownership structure" is the closest term available for discussing the subject. See Jill Frances Solomon, Aris Solomon \& Chang-Young Park, The Evolving Role of Institutional Investors in South Korean Corporate Governance: Some Empirical Evidence, 10 Corp. Governance: INT'L Rev. 211, 211 (2002). This lack of direct translation may be a minor coincidence. But the fact that a certain language lacks a term for a social concept laden with connotations such as corporate governance could indicate that this concept may have a more marginal role in people's thinking. Maybe this is another coincidence, but one may note that Japanese lacks a word for accountability, using the transliteration akauntabiritii instead. See AMIR N. Licht, Accountabiltry and Corporate Governance (Working Paper, 2002). 
rulers. ${ }^{60}$ The initial wealth of the chaebols originated from the government sale of properties owned by Japanese colonizers and of other resources to their founding families. ${ }^{61}$ However, the government prohibited the chaebols from owning private banks, partly in order to increase its own leverage over the banks in areas such as credit allocation.

A characteristic feature of the chaebols is that they are largely controlled by their founding families. Family control over the chaebol does not rest on direct holding of majority blocks of shares. Rather, chaebols exhibit intricate networks of cross-holdings among numerous companies such that family members enjoy effective control without owning even half of the cash flow rights. Such holding structures are known to engender severe agency problems. ${ }^{62}$ As part of the IMF-mandated reforms in the wake of the 1997 crisis, controlling families were required to reduce their holdings in the largest chaebols. Nevertheless, while the equity share of family members declined from 14 percent to 4.5 percent by 2000 , the total in-group holding remained steady. ${ }^{63}$ This renders outside challenge to the management control of the major families virtually impossible. ${ }^{64}$

The strong familial character of the chaebols manifests itself in numerous aspects of their management and operation. At the head of chaebols stands the chairman, who in the past also used to be the head of the founding family; however, the chairman does not formally hold a directorship position in many group companies. ${ }^{65}$ The chairmanship position traditionally moved to the chairman's eldest son or to another close kin. ${ }^{66}$ The board of directors used to be composed of only executive directors practically appointed by the chairman. Other top positions in the chaebols were generally staffed with members of the extended family. Professional managers too are more concerned with satisfying the dominant family than meeting the needs of the firm or its shareholders. ${ }^{67}$ Organization and management in the chaebols are extremely hierarchical, mir-

60. Literally meaning "business conglomerate," chaebol is the Korean pronunciation of the Chinese symbols that Japanese pronounce Zaibatsu. Although it is widely used by non-Koreans, Song notes that when Koreans use the word chaebol it is in a disparaging sense (due perhaps to its colonial lineage). SonG, supra note 55, at $x$.

61. Sang-Woo Nam, Business Groups Looted by Controlling Families, and the Asian CRISIS 13 (ADB Institute, Working Paper 27, 2001).

62. See Lucian A. Bebchuk, Reinier Kraakman \& George Triantis, Stock Pyramids, CrossOwnership and Dual Class Equity: The Mechanisms and Agency Costs of Separating Control from Cash-Flow Rights, in Concentrated CORPORATE OWNERShIP 295 (Randall Morck ed., 2000).

63. In tandem, the limit on a chaebol member firm's holding of affiliated company shares had been moderated from 25 to 40 percent of the company's net assets. Letter from Kon Sik Kim to Author (Oct. 3, 2002) (on file with author).

64. Nam, supra note 61, at 18. See also. Daehong T. JAANG, Kyung-Soo Kim, Woo Tack Kim \& Sangsoo Park, Cross Shareholding And Corporate Financial Policy: the Case of KOREA (Working Paper, 2002) (explaining that cross-holdings in the chaebols allow the heads of the founding families to exert dominant control power without supply of real capital).

65. Id. at 20.

66. NAM, supra note 61 , at 21 table 3 (summarizing data about succession patterns for chaebol chairmanship in the largest chaebols until 1996; out of 35 such successions, only one was to a professional manager and 34 were to family members, out of which 20 were to the eldest son.)

67. See Curtis J. Milhaupt, Privatization and Corporate Governance in a Unified Korea, 26 IOWA J. CORP. L. 199, 206 (2001). 
roring the structure of Korean families and clans. Formal control mechanisms were absent, as the statutory-mandated auditors were never truly functional. This authoritarian, opaque, and familial management style was in fact valued and envied by many Koreans, according to some accounts. ${ }^{68}$ Commentators unanimously relate these features to Korea's long Confucian heritage. ${ }^{69}$

\section{The Legal Environment}

The legal infrastructure for corporate governance in Korea rests on its Commercial Code of 1962 (the Code). ${ }^{70}$ Continuing the historical influence of Japan over Korea, the Korean Code mirrors the Japanese Commercial Code of 1950. The Japanese Code is an amalgam of a German commercial code and numerous amendments that were introduced into Japanese law by the American occupation forces in the late 1940s. Another statutory pillar for corporate governance is the Korean Securities and Exchange Act, which has a similar Japanese-American heritage (but without German roots). The present article will only briefly highlight some of the major changes Korean law has undergone in recent years. ${ }^{71}$ Already in 1995 (effective October 1996) - and well before the 1997 financial crisis occurred-Korea amended the Code in various parts to enhance the international competitiveness of Korean companies.

After Korean corporate governance was cited by the IMF as one of the major causes of the 1997 crisis, $^{72}$ additional rounds of amendments took place between 1998 and 2000. These amendments were primarily inspired by American law and American practices, although these were not the only sources. ${ }^{73}$ In 1999 , the OECD completed a code of corporate governance principles intended

68. SonG, supra note 55, at 194 (describing how the chairman of the Hyundai group used to open his working day with a breakfast together with his four Hyundai top executive sons).

69. See infra subsection (4).

70. This section draws on Joongi Kim, Recent Amendments to the Korean Commercial Code and their Effects on International Competition, 21 U. PA. J. INT'L EcoN. L. 273 (2000); Kim, supra note 57; Kon Sik Kim \& Joongi Kim, Revamping Fiduciary Duties in Korea: Does Law MatTER IN Corporate Governance? (Working Paper, 2002).

71. For detailed analyses, see supra note 70. See also Jooyoung Kim \& Joongi Kim, Shareholder Activism in Korea: A Review of How PSPD Has Used Legal Measures to Strengthen Korean Corporate Governance, 1 J. Korean L. 51 (2001); Hwa-Jin Kim, Toward the "Best Practice" Model in a Globalizing Market: Recent Developments in Korean Corporate Governance, 2 J. CoRP. L. STUD. 345 (2002).

72. See Tomas J.T. Balino \& Angel Ubide, The Korean Financial Crisis of 1997: A StRATEGY FOR FinANCIAL Sector ReForm (IMF Working Paper, WP/99/28, 1999); Magdi Iskander et al., Corporate Restructuring and Governance in East Asia, 36(1) FIN. \& Dev. 42 (1999), available at $\mathrm{http}: / / \mathrm{www} . i m f . o r g / e x t e r n a l / p u b s / \mathrm{ft} /$ fandd/1999/03/iskander.htm.

73. A contested document in this regard was an expert committee report commissioned by the Ministry of Justice and headed by Bernard Black, which proposed a very long list of amendments. Corporate Governance in Korea at the Millennium: Enhancing International CompetiTIVENESS, Final Report and Legal Reform Recommendations to the Ministry of Justice of the Republic of Korea (May 15, 2000), available at http://papers.ssm.com/paper.taf?abstract _id=222491. This report has met with strong objection from the business sector and, as of August 2002, was not implemented. See Stephen J. Choi \& Kon-Sik Kim, Establishing a New Stock Market for Shareholder Value Oriented Firms in Korea, 3 CH. J. INT'L L. 277 n.22 (2002); Letter from Kon-Sik Kim, Seoul National University, to Author, Aug. 20, 2002 (on file with author). 
for use both by its members and every other country. ${ }^{74}$ These principles were adopted by the IMF and the World Bank as a standard recommended platform for corporate governance reform; ${ }^{75}$ they were also adopted by CalPERS to guide its international investment strategy. ${ }^{76}$ The core principle of these projects is the promotion of "the equitable treatment of shareholders" "7 - something that few would object to. Evidence from Korea showed that minority shareholders were indeed exploited by the chaebols' controlling families. ${ }^{78}$

Although the OECD Principles are non-binding, there is considerable convergence toward them as an optimal corporate governance framework. ${ }^{79}$ In accordance with the Principles, the major amendments to the Korean laws included (1) introducing a formal fiduciary duty of loyalty; ${ }^{80}(2)$ introducing an option for companies to establish audit committees with a majority of non-executive directors; (3) establishing various minority shareholder rights, including a reduction in the minimum shareholding required for filing derivative suits; (4) requiring listed companies to have at least one outside director out of every four; (5) introducing cumulative voting; (6) requiring shareholder approval for major transactions. ${ }^{81}$

It is too early to judge the success of these major legislative reforms. Naturally, there has been strong objection to the reforms from the chaebol controlling families. ${ }^{82}$ A bill to establish shareholder class actions failed to pass the legislative body, ${ }^{83}$ and a comprehensive reform plan commissioned by the Ministry of Justice was put on ice. ${ }^{84}$ On the bright side, the Korean courts recently handed down several landmark decisions, imposing liability on managers for breach of fiduciary duty. ${ }^{85}$ The People's Solidarity for Participatory Democracy (PSPD), an important civic group campaigning for corporate governance reform, has taken various steps to block dubious transactions in the Hyundai group. ${ }^{86}$ On the other hand, at least several reforms have been implemented according to the letter of the law but quite against its spirit. For example, some firms staffed the

74. OECD PRINCIPLES, supra note 5.

75. Organization for Economic Development and Co-operation, a framework for Co-Operation betweEn THE OECD AND THE WORLd BANK (1999). A related project of "best corporate governance principles" is reflected in Gainan Avilov et al., General Principles of Company Law for Transition Economies, 24 J. CORP. L. 190 (1999).

76. For a review, see Amir N. Licht, The Mother of All Path Dependencies: Toward a CrossCultural Theory of Corporate Governance Systems, 26 DEL. J. CoRP. L. 147, 154-65 (2001).

77. OECD PRINCIPLES, supra note 5, at 6.

78. See, e.g., NAM, supra note 61; Milhaupt, supra note 67, at 206; KEE-Hong BAE, JUN-KoO Kang \& Jin-Mo KIM, Tunneling or Value AdDImon? Evidence from Mergers by Korean Business Groups (Working Paper, 2000), available at http://papers.ssrn.com/sol3/papers.cfm?abstract_id=246621.

79. See, Kim, supra note 57.

80. For a thorough discussion of fiduciary duties, see KIM \& KIM, supra note 70.

81. See Hwa-Jin Kim, supra note 71 , at 7-12.

82. See Black, supra note 1, at 542-43; CHOI \& Kim, supra note 73, at 6.

83. See Hwa-Jin Kim, supra note 71 , at 9.

84. See supra note 73 .

85. See KIM \& KIM, supra note 70.

86. See Jill Frances Solomon, Aris Solomon \& Chang-Young Park, A Conceptual Framework for Corporate Governance Reform in South Korea, 10 CoRP. GovernanCE: INT'L Rev. 29, 34-35 (2002); Lim, supra note 55, at 30. 
required quota of outside directors and newly-established audit committees with people close to the controlling families. At times, even the government seemed to disregard the basic principles of corporate governance and encouraged the founder families to revert to their old ways by urging profitable companies to rescue their "brother" companies in distress. ${ }^{87}$ Overall, "the government's interest in undertaking further reforms now seems on the wane." 88

At least regarding cross-listing, however, the Korean government seems determined to promote reform. As part of modernizing Korea's equity market, and in tandem with establishing KOSDAQ as a market for start-up companies, the government took steps to allow Korean issuers to cross-list their stocks on nine foreign stock markets. ${ }^{89}$ Among the reasons cited by the government for the new rules was "enhancing the transparency and efficiency in management and corporate governance by means of globalization of the disclosure system, accounting system and practice in the securities industry." cial Supervisory Commission promulgated rules intended to equalize the information provided to the Korean market by such dual-listed issuers with the information they disclose in foreign exchanges. ${ }^{91}$

Korea's economic recovery came in 1999 , before all the reforms were promulgated. Thus, a lingering question remains regarding any causal relations between Korea's structural and institutional problems, the reforms, and the recovery. For the present purposes, we are interested in the degree to which the reforms could diminish the virtual distance between Korea's corporate governance system and the features that may be more highly valued in international securities markets. An investigation of Korea's social infrastructure, its Confucian heritage, is the next step in this inquiry.

\section{The Confucian Heritage}

In brief, the Confucian ideal of social structure rests on the "Five Relationships." Formulated by classical Chinese philosophers, this concept states that there should be affection between father and son, righteousness between ruler and minister, attention to separate functions between husband and wife, proper order between old and young, and faithfulness between friends. The Confucian ethic places a unique emphasis on the family. Filial piety probably is the central value. In the traditional extended-family system, the needs of the family have priority over individual investigational needs; indeed, Korean familial relations

87. See Lim, supra note 55 , at 29-30.

88. ChOI \& KIM, supra note 73 , at 6.

89. See supra note 13. The stock exchanges are the NYSE, NASDAQ, AMEX, and those of London, Frankfurt, Paris, Tokyo, Hong Kong, and Singapore.

90. Hwa-Jin Kim, Improving Corporate Governance and Capital Markets Through CrossListing on Foreign Exchanges, 44 Korea SEc. Depository Q. J. 3 (2003) (Korean) (English summary on file with author) (citing Korea Financial Supervisory Commission Internal Memo re CrossListing of Public Companies on Foreign Exchanges, Jan. 18, 2002 (Korean)). The government opined that "cross-listing will act as catalyst for improving the disclosure system and accounting system of the Korean companies." Id.

91. Kim, supra note 90 (citing Art. 69 para. 1 No. 18 and para. 6 of the Korea Financial Supervisory Commission Regulation on the Issuance of Securities and Disclosure). 
do not draw a sharp line between members of the extended family and members of the wider clan, a patrilineal group that defines itself in terms of a common distant ancestor. ${ }^{92}$ In terms of organization structure, Confucianism champions strict hierarchical structures. This begins with the family in which the father is the source of authority, loyalty runs to him, and responsibility for family members rests with him. This paternal hierarchy extends to other social contexts.

Confucianism was Korea's state philosophy during the reign of the Choson dynasty (1392-1910), which lasted for more than five hundred years, until Korea was colonized by Japan. ${ }^{93}$ The country is the most ethnically homogenous country in the world; ${ }^{94}$ it is also among the oldest continuously existing countries. ${ }^{95}$ Compared with other countries with a Confucian heritage, Korea is said to be the most Confucian in the world. ${ }^{96}$ It is therefore not surprising that commentators widely agree that the Korean corporate governance system reflects features of Confucian culture. It should be noted that Korea also has a significant Christian population, the largest in Asia. Some scholars claim that as a result, Korea developed a mix of the Confucian ethic and the Protestant Puritan ethic (as defined by Max Weber). ${ }^{97}$

\section{B. Comparing Cultures}

\section{The Problem}

Thus, Korea is a fascinating country with a rich culture that emphasizes the family and shares some features of its rich culture with some, but not all neighboring Asian countries. How should knowledge of Korea's cultural heritage inform foreign investors in Korean ADRs or policymakers contemplating corporate governance reform? Recall that for particular issuers, these two contexts are conceptually identical. In both cases, the established Korean corporate governance system would be enhanced with foreign elements. In the case of corporate governance, American-inspired corporate governance features are directly transplanted into Korean law. In the case of Korean ADRs, American provisions constitute an additional normative layer, as issuers become subject to (diluted $)^{98}$ U.S. disclosure rules, accounting standards, and so forth. Issuers can

92. SoNG, supra note 55 , at 55 .

93. Id. at 10 . Confucianism is often also mentioned as the state religion during that time. However, the crucial point here is its being the state philosophy. As such, Confucianism could shape secular social institutions irrespective of people's religious denomination and the degree of their religious commitment. 2003).

94. Alberto Alesina et al., Fractionalization 8 (NBER, Working Paper No. 9411,

95. Song, supra note 55 , at 10 .

96. Id. Among other Asian countries, Japan is more culturally diverse and China has undergone periods of severe internal turmoil.

97. SONG, supra note 55, at 52-56 (citing Tu Wei-Ming, Confucian Ethics Today (1984)). For Weber's viewpoint, see MaX Weber, The Protestant Ethic and the Spirtt of Capitalism (Talcott Parsons trans., 1958).

98. The U.S. disclosure regime applicable to foreign issuers is inferior to the regime that applies to domestic American issuers especially on issues of corporate governance. See Licht, Bonding or Avoiding, supra note 10. 
even eschew the common practice among non-U.S. issuers to seek an exemption from stock-exchange listing rules on corporate governance. ${ }^{99}$ Does Korea's culture pose a problem to such enhanced regimes?

In principle, if the incentives are correctly set, one can uphold Confucian values and still maximize shareholder wealth. The expert committee report to the Korean Ministry of Justice addressed this issue as follows:

We believe strongly that reforms must fit within a country's existing laws and institutions. They cannot just be airlifted in from outside. . . We don't believe that Korea's supposed autocratic, Confucian culture will simply shrug off measured efforts to control self-dealing and improve oversight of corporate managers. Even Confucian managers respond to incentives. ${ }^{100}$

Granted they do. But what may worry potential investors in Korean stocks or ADRs is that in comparison to American managers, Confucian insiders may respond to incentives differently-assuming, plausibly, that greed is universal. Korean commentators in fact voice concerns that without more, the legal reforms undertaken so far may not suffice for remedying Korea's corporate governance. ${ }^{101}$ By analogy, any extra investor protection provided by cross-listing on an American stock market under the bonding hypothesis may also turn out to be ineffective.

The case of Korea exemplifies a general intuition among experts that culture matters for corporate governance. ${ }^{102}$ Until recently, however, mostly anecdotes were offered to substantiate this point, ${ }^{103}$ which clearly cannot guide

99. See American Bar Association, Section of Business Law, Committee on Federal Regulation of Securities, Special Study on Market Structure, Listing Standards AND Corporate Governance 26 (May 17, 2002), cited in Coffee, supra note 32, at 29.

100. Black, supra note 1, at 545 (italics added; footnote omitted). The omitted footnote cites Craig P. Ehrlich \& Dae-Seob Kang, Corporate Governance Reform In Korea: A Descrip. tion Of Legal Changes and Suggestions for Empirical Research (Working Paper, 1999) (arguing that the IMF-mandated reforms are incompatible with Korea's Confucian culture). See Craig Ehrlich \& Dae-Seob Kang, U.S. Style Corporate Governance in Korea's Largest Companies, 18 UCLA PAC. BAsin L.J. 1, 2 (2000) ("The Korean government retained a U.S. law firm and a U.S. law professor to advise it, and the new laws have imported U.S. style governance concepts. The Korean corporate culture is radically different, however, and a serious question is whether U.S. legal mechanisms can be airlifted into a Confucian culture."). Ehrlich and Kang, however, do not specify in much further detail why the Korean system should reject the proposed laws.

101. See CHOl \& KIM, supra note 73, at 4 ("[T] not effect large changes in the overall level of protections for minority investors. Indeed, the law itself may in fact matter less. Culture, for example, may play a larger role in how often controlling shareholders and managers expropriate value from minority investors."); Park, supra note 57, at 25 ("The restructuring that took place both in financial and corporate sectors so far was, however, more of adjustments in "hardware'... [M] ending some corporate governance laws would prove relatively easier than reforming the actual practice."); LIM, supra note 55, at 30 ("[T]he feudalistic infighting for corporate control at the Hyundai Group illustrated that Korean firms had changed very little with regard to corporate govemance."); Kim, supra note 57, at 35 ("It may be at least questionable whether the OECD Principles indeed offer guide and help in dealing with the corporate governance problems in Korea.").

102. For a review, see Licht, supra note 76, at 160-66. See René M. Stulz \& Rohan Williamson, Culture, Openness, and Finance, J. Fin. Econ. (forthcoming 2004) (citing economic historian David Landes, Culture Makes Almost All of the Difference, in CuLTURE MATTERS 2 (Lawrence E. Harrison \& Samuel P. Huntington eds., 2000)).

103. See, e.g., Lucian Arye Bebchuk \& Mark J. Roe, A Theory of Path Dependence in Corporate Ownership and Governance, 52 STAN. L. REv. 127, 169 (1999) ("American culture, for exam- 
policy formation nor investment strategies. ${ }^{104}$ Two strands of psychological research have developed insights that should be useful for better understanding the implications of foreign corporate governance systems. ${ }^{105}$ The next two subsections describe ways for taking up this challenge-first, with regard to cultural values, and next, with regard to cognitive styles.

\section{Value Dimensions}

Cross-cultural psychologists have made considerable advances over the last two decades toward developing a universal analytical framework for comparing cultures. ${ }^{106}$ Defined in subjective terms, culture is the values, orientations and underlying assumptions that are prevalent among the members of a society. ${ }^{107}$ A common postulate in cross-cultural psychology is that all societies confront similar basic issues or problems when they come to regulate human activity. The cultural responses to the basic problems that societies face are reflected in prevailing value emphases. ${ }^{108}$ Because values vary in importance, it is possible to characterize societies by the relative importance attributed to these values in the society using dimensional models. This yields unique cultural profiles for societies or countries. ${ }^{109}$

A pioneering and still influential dimensional framework for characterizing cultures was advanced by Geert Hofstede, ${ }^{110}$ which is used today in studies on

ple, resists hierarchy and centralized authority more than, say, French culture. German citizens are proud of their national codetermination. Italian family firm owners may get special utility from a longstanding family-controlled business, while an American family might prefer to cash the company earlier and run the family scion for the U.S. Senate.") (footnote omitted); Bernard S. Black, Agents Watching Agents: The Promise of Institutional Investor Voice, 39 UCLA L. Rev. 811, 831 (1992) (arguing that non-regulatory constraints on American managers' opportunism include "cultural norms of behavior").

104. For detailed treatments of cultural aspects in corporate governance and securities regulation from a political economy perspective, see Curtis J. Milhaupt, A Relational Theory of Japanese Corporate Governance: Contract, Culture, and the Rule of Law, 37 HARv. INT'L L. J. 3 (1996); James A. Fanto, The Absence of Cross-Cultural Communication: SEC Mandatory Disclosure and Foreign Corporate Governance, 17 Nw. J. INT'L L. \& Bus. 119 (1996).

105. In addition to psychology, the disciplines that have been dealing with cultural comparisons include anthropology and political science. See generally, Clifford GeERTz, The Interpretation of Cultures: Selected Essays (1973); Michael Thompson, Richard Ellis, \& Aaron Wildav. sky, Cultural Theory (1990); Ronald Inglemart, Modernization and Postmodernization: Cultural, Economic and Political Change in 43 Societies (1997).

106. The text only summarizes the core features of the two leading models in this field. For a general accessible introduction to cross-cultural psychology and additional sources, see Licht, supra note 76. For further details, see Shalom H. Schwartz, Cultural Value Differences: Some Implications for Work, 48 APPL'D Psychol. INT'L Rev. 23 (1999).

107. This definition is similar to that adopted in studies of the effects of societal development, for example, Culture Matters: How Values Shape Human Progress (Lawrence E. Harrison \& Samuel P. Huntington eds., 2000), and widespread in cross-cultural psychology, for example, HANDbook of Cross-Cultural Psychology (J.W. Berry, M.H. Segall \& C. Kagitcibasi eds., 2nd ed. 1997).

108. See, e.g., Milton Rokeach, The Nature of Human Values (1973); Florence R. Kluckhohn \& Fred L. Strodtbeck, Variations in Value Orientations (1961).

109. For details on the statistical tools used for producing dimensional profiles, see Licht, supra note 76 , at $170-75$.

110. See Geert H. Hofstede, Culture's Consequences: International Differences in Work-Related Values (1980) [hereinafter Culture's Consequences 1980]; Geert Hofstede, 
management and accounting. ${ }^{111}$ Hofstede ultimately identified five value dimensions: ${ }^{12}$ Individualism/Collectivism, Power Distance, Uncertainty Avoidance, Masculinity/Femininity, ${ }^{113}$ and Long-term Orientation. ${ }^{114}$ Another important theory was developed mostly during the 1990s by Shalom Schwartz. ${ }^{15}$ Schwartz defines three cultural value dimensions: Embeddedness/Autonomy, Hierarchy/Egalitarianism, and Mastery/Harmony. Tables 1 and 2, respectively, set forth the Hofstede and Schwartz value dimensions and the basic societal problems they address. Each dimension describes a range of possible societal stances between two polar extremes.

Based on their value priorities, countries can further be classified into cultural regions. Hofstede's analysis yielded the following regions: Anglo, Germanic, Nordic, two Latin regions, two Asian regions (one consisting only of Japan), and Near Eastern. ${ }^{116}$ Six cultural groups of nations were identified by Schwartz: English-speaking, West European, East European, Far Eastern, Latin American, and African. ${ }^{117}$ A broader, more recent sample suggests that the Far Eastern cultural region comprises two sub-regions: South Asian and Confucian. ${ }^{118}$ The latter region consists of China, Hong Kong, Taiwan, South Korea, Singapore, and Japan - though Japan differs some from the others.

Culture's Consequences: Comparing Values, Behaviors, Institutions, and Organizations Across Nations (2d ed. 2001) [hereinafter Culture's Consequences]; Geert H. Hofstede, CultURES AND ORganizations: Software of tHe Mind (1991) [hereinafter Software of THE Mind].

111. See Peter B. Smith, The End of the Beginning?, 1 Int'L J. Cross-Cultural Mgmt. 21 (2001). See also Stephen P. Robbins \& Mary Coulter, Management 125-29 (6th ed. 1999) (arguing that " $[t]$ he most valuable framework to help managers better understand differences between national cultures was developed by Geert Hofstede."); Richard Mead, INTERNational MaNagement: Cross-Cultural Dimensions (2nd ed. 1998) (drawing on Hofstede's theory); Graeme L. Harrison \& Jill L. McKinnon, Cross-Cultural Research in Management Control System Design: A Review of the Current State, 24 AcCT. ORG. \& Soc. 483 (1999) (same). Hofstede's work has also stirred objections on various grounds over the years. For a review and discussion of common objections, see Hofstede, Culture's ConsequenCEs, supra note 110, at 73.

112. The names of value dimensions are capitalized throughout to notify that these are terms of art whose definitional meaning might differ from the common usage of these words.

113. This label has elicited negative responses. Writing originally in 1980, Hofstede was well aware of the problems of attributing certain qualities to particular genders. He nonetheless kept this dimension, arguing that it reflects a positive reality that is independent of its normative undesirability. Hofstede, Culture's Consequences 1980 , supra note 110 , at 189-90. In the 2001 edition, Hofstede follows the modern distinction between sex and gender and uses the latter term when referring to social function. Hofstede, Culture's Consequences, supra note 110, at 280. For further discussions, see Geert H. Hofstede \& Willem A. Arrindell, Masculinity and Femininrty: The Taboo Dimension of National Cultures (1998).

114. This value dimension was not included in Hofstede's original study. It was added later, in Hofstepe, Software of the Mind, supra note 110, in light of a study led by Michael Bond. There, it was named "Confucian work dynamism." See The Chinese Cultural Connection, Chinese Values and the Search for Culture-Free Dimensions of Culture, 18 J. Cross-Cultural Psychol. 143 (1987). Notwithstanding its apparent link to Asian cultures, data for this dimension cover a smaller set of countries and it is not commonly used in the literature.

115. See Schwartz, supra note 106

116. Hofstede, Culture's Consequences 1980, supra note 110, at 333-36. Note that the classification into more and less economically developed cultural regions dates from 1980.

117. Schwartz, supra note 106 , at $35-39$.

118. Shalom H. Schwartz, Relations of Culture to Social Structure, Demography and Policy in the Study of Nations, Invited Lecture Delivered at the 25th International Congress of Applied Psychology, Singapore, July 2002 (on file with author). 
Table 1. The Hofstede Value Dimensions

\begin{tabular}{|l|l|}
\hline Individualism/Collectivism & $\begin{array}{l}\text { Valuing loosely knit social relations in which individuals are } \\
\text { expected to care only for themselves and their immediate fam- } \\
\text { ilies versus tightly knit relations in which they can expect their } \\
\text { wider in-group (e.g., extended family, clan) to look after them } \\
\text { in exchange for unquestioning loyalty. }\end{array}$ \\
\hline Power Distance & $\begin{array}{l}\text { Accepting an unequal distribution of power in institutions as } \\
\text { legitimate or illegitimate. }\end{array}$ \\
\hline Uncertainty Avoidance & $\begin{array}{l}\text { Feeling uncomfortable or comfortable with uncertainty and } \\
\text { ambiguity and therefore valuing or devaluing beliefs and insti- } \\
\text { tutions that provide certainty and conformity. }\end{array}$ \\
\hline Masculinity/Femininity & $\begin{array}{l}\text { Valuing achievement, heroism, assertiveness, and material } \\
\text { success versus relationships, modesty, caring for the weak, } \\
\text { and interpersonal harmony. }\end{array}$ \\
\hline Long-Term Orientation & $\begin{array}{l}\text { Having a long-term time orientation; emphasizing Confucian } \\
\text { work ethics such as thrift and persistence. }\end{array}$ \\
\hline
\end{tabular}

Table 2. The Schwartz Value Dimensions

\begin{tabular}{|l|l|}
\hline Embeddedness/Autonomy & $\begin{array}{l}\text { This dimension concerns the desirable relationship between } \\
\text { the individual and the group. Embeddedness represents a cul- } \\
\text { tural emphasis on maintenance of the status quo, propriety, } \\
\text { and restraint of actions or inclinations that might disrupt the } \\
\text { solidary group or the traditional order. Autonomy describes } \\
\text { cultures in which the person is viewed as an autonomous, } \\
\text { bounded entity who finds meaning in his or her own unique- } \\
\text { ness. }\end{array}$ \\
\hline Hierarchy/Egalitarianism & $\begin{array}{l}\text { This dimension concerns guaranteeing responsible behavior } \\
\text { that will preserve the social fabric. Hierarchy refers to a cul- } \\
\text { tural emphasis on obeying role obligations within a legiti- } \\
\text { mately unequal distribution of power, roles, and resources. } \\
\text { Egalitarianism refers to an emphasis on transcendence of self- } \\
\text { ish interests in favor of voluntary commitment to promoting } \\
\text { the welfare of others. }\end{array}$ \\
\hline Mastery/Harmony & $\begin{array}{l}\text { This dimension concerns the relation of humankind to the nat- } \\
\text { ural and social world. Mastery refers to a cultural emphasis on } \\
\text { getting ahead through active self-assertion whereas Harmony } \\
\text { refers to an emphasis on fitting harmoniously into the environ- } \\
\text { ment. }\end{array}$ \\
\hline
\end{tabular}

These theories and data make it possible to make systematic observations about Korea's culture. In Hofstede's regional classification, Korea is part of the Asian region. Its scores on Hofstede's dimensions reflect societal preferences for high Collectivism, high Uncertainty Avoidance, moderately high Power Distance, moderate Masculinity, and high Long-term Orientation. ${ }^{19}$ In the

119. Hofstede, Culture's Consequences, supra note 110 , at 500. Hofstede's scores are based on surveys that were conducted in the late 1960s and early 1970s. Since that time, Korea has experienced massive changes in its economic and political conditions-a fact that could affect its cultural values. Jong-Seo Choi provides a knowledgeable discussion of this issue and argues that Koreans have become more individualist and less uncertainty avoiding. This is a plausible assertion. 
Schwartz data, Korea's scores reflect societal preferences for Embeddedness over Autonomy, for Hierarchy over Egalitarianism, and for Mastery over Harmony. This profile is consonant with many analyses of Confucian culture. ${ }^{120}$ Overall, the cultural profiles under the two dimensional theories are congruent with one another. Hence, the nature of Korea's culture as Confucian, autocratic, and collectivist, or embedded, has concrete empirical support. ${ }^{121}$

\section{Cognitive Styles}

For several decades, most psychologists have assumed that basic cognitive processes are universal: Every human being is equipped with the same set of attentional, memorial, learning, and inferential procedures. ${ }^{122}$ Cognitive scientists' endorsement of the universalistic position was encouraged by the analogy between the human mind and the computer: brain equals hardware, cognitive procedures equals operating principles and factory-installed software. ${ }^{123}$ The heuristics and biases movement started by Kahneman and Tversky encouraged the view that procedures such as judgment of probability by the representativeness heuristic and judgment of frequency by the availability heuristic, were primary, universal, and difficult to alter. ${ }^{124}$

Evidence since the late 1990s now casts doubt on the universality assumption about cognitive processes. Studies indicate that cognitive styles differ markedly across cultures. People from different cultures perceive, understand, and judge the world in systematically different ways. Cultural differences in cognitive processes are further tied to cultural differences in basic assumptions about the nature of the world. Finally, cultural practices encourage and sustain certain kinds of cognitive processes, which then perpetuate the cultural practices. $^{125}$

However, Choi's detailed description of contemporary prevailing values actually confirms Korea's profile as a society that is still high on Collectivism and Uncertainty Avoidance. Choi's conclusions about Korea's accounting system are consistent with this view. See Jong-Seo Choi, Financial Crisis and Accounting Reform: A Cultural Perspective (Working Paper 2001). See infra note 176.

120. Hofstede, Culture's Consequences, supra note 110.

121. See supra note 100 .

122. This is only one basic assumption. The literature on culture and cognition is outpouring. See Richard E. Nisbett \& Ara Norenzayan, Culture and Cognition, in Stevens' HandBook of Experimental Psychology: Cogntrion 561 (D. L. Medin ed., 3rd ed. 2001); Richard E. Nisbett et al., Cultures as Systems of Thought: Holistic versus Analytic Cognition, 108 Psychol. Rev. 291 (2001); Kaiping Peng, Daniel R. Ames \& Eric Knowles, Culture and Human Inference, in HandBook of Culture and Psychology 245 (D. Matsumoto ed., 2001); Alan P. Fiske et al., The Cultural Matrix of Social Psychology, in HANDBook of Social Psychology 915 (D. T. Gilbert, S. T. Fiske \& G. Lindzey eds., 4th ed. 1998).

123. Nisbett \& Norenzayan, supra note 122, at 561 (citing N. Block, The Mind as the Software of the Brain, in Thinking: An Invitation to the Cognitive Science 377 (E. E. Smith \& D. N. Osherson eds. 1995)). Note, anecdotally, that Hofstede considered culture to be the software of the mind. Hofstede, SofTware of THE Mind, supra note 110.

124. Nisbett \& Norenzayan, supra note 122 , at 561. For a law-oriented discussion, see Donald C. Langevoort, Behavioral Theories of Judgment and Decision Making in Legal Scholarship: A Literature Review, 51 VAND. L. REv. 1499 (1998). See also Christine Jolls, Cass R. Sunstein, \& Richard Thaler, A Behavioral Approach to Law and Economics, 50 Stan. L. REv. 1471 (1998).

125. Nisbett \& Norenzayan, supra note 122, at 561-62. 
The vast majority of empirical studies compared Western (mostly American) subjects with East Asian (mostly Chinese and Korean) subjects. For instance, Americans were more inclined to assign causality and responsibility to individual group members in agency situations, while the Chinese were more inclined to assign them to attributes of the group as a whole. ${ }^{126}$ In explaining causes of behavior, Koreans, more so than Americans, placed credence on situational and interactional factors. ${ }^{127}$ Koreans were also better able than Americans to recognize the influence of situational constraints on individual behavior: Americans were more susceptible to the fundamental attribution error. ${ }^{128}$ On the other hand, Koreans were more susceptible to the hindsight bias, believing that they could have predicted outcomes that in fact one could not have predicted. ${ }^{129}$ This finding may stem from the fact that in analyzing a situation, Koreans consider more factors as relevant than Americans do. ${ }^{130}$

To conceptualize the differences between subjects' cultures, researchers draw on the distinction between conceptions of the self as independent versus interdependent, as suggested by Markus and Kitayama. ${ }^{131}$ In this view, the Western construal of the self is characterized by a sense of autonomy and distinctiveness from others. In the East Asian construal of the self, one's identity is diffused socially across significant others in one's in-group. ${ }^{132}$ These polar views resemble Schwartz's Autonomy/Embeddedness dimension and are also reminiscent of, but not identical to, Hofstede's and Triandis's Individualism/ Collectivism distinction. ${ }^{133}$ Explanations for these, and many other striking cultural differences in cognitive styles call upon differences in reasoning traditions with ancient roots-possibly traced to the era of Confucius and Aristotle. ${ }^{134}$

\section{Measuring Cultural Distance}

To examine some empirical evidence of the implications of cultural differences on corporate governance, it is useful to explore the concept of cultural distance. Conceptually, the cultural distance between nations represents "the sum of factors creating, on the one hand, a need for knowledge, and on the other

126. Tanya Menon et al., Culture and the Construal of Agency: Attribution to Individual Versus Group Dispositions, 76 J. Personality \& Soc'l Psychol. 701 (1999).

127. Ara Norenzayan, Incheol Choi \& Richard E. Nisbett, Cultural Similarities and Differences in Social Inference: Evidence from Behavioral Predictions and Lay Theories of Behavior, 28 PERSONALITY \& Soc'l Psychol. Bul. 109 (2002).

128. Incheol Choi \& Richard E. Nisbett, Situational Salience and Cultural Difference in the Correspondence Bias and Actor-Observer Bias, 24 PersonaltTy \& Soc'l Psychol. Bul. 949 (1998).

129. Incheol Choi \& Richard E. Nisbett, The Cultural Psychology of Surprise: Holistic Theories and Recognition of Contradiction, 79 J. Personality \& Soc'L Psychol. 890 (2000).

130. Nisbett \& Norenzayan, supra note 122, at 585 (citing InCHEOL ChOI, R. DALAL \& C. KIMPrieto, Information Search In Causal attribution: Analytic vs. Holistic (University of Illinois, Working Paper, 2000)).

131. Hazel R. Markus \& Shinobu Kitayama, Culture and the Self: Implication for Cognition, Emotion, and Motivation, 98 Psychol. Rev. 224 (1991).

132. Peng et al., supra note 122, at 248.

133. See Harky C. Triandis, Individualism and Collectivism (1995).

134. See Fiske et al., supra note 122, at 322-24. 
hand, barriers to knowledge flow and hence also for other flows between the home and the target countries." 135 The discussion thus far has shown that the notion of countries' cultures differing goes beyond lay intuitions and can be analyzed systematically. By extracting the most fundamental differences among cultures and operationalizing them in numerical data, the cultural value dimension framework then allows for the generation of testable hypotheses and further empirical investigation through cross-sectional samples. The legal and economic literature has not yet taken advantage of this powerful tool. ${ }^{136}$ However, as noted above, international business scholars rely extensively on Hofstede's theory and data. Based on this framework, this line of scholarship has also developed a numerical measure for cultural distance.

To understand the operationalization of cultural distance, consider nations' scores on each of the cultural value dimensions as coordinates on a grid or in a space. Hofstede's original framework thus defines a four-dimensional space. Cultural distance between two particular countries in this context would consist of some weighted average of the differences between these countries' scores on the four dimensions. A seminal study by Kogut and Singh investigated American corporations' mode of entry into business in foreign countries and specifically the hypothesis that differences in cultures among countries influence the perception of managers regarding the costs and uncertainty of alternative modes of entry. ${ }^{137}$ To test this proposition empirically, Kogut and Singh developed a composite index of cultural distance based on the deviation along Hofstede's dimensions. The index consisted of the average of the square difference between the scores of the United States and the other country on each dimension, weighted by the variance of this dimension. Subsequent studies have used Kogut and Singh's measure, sometimes with adaptations or simplifications. ${ }^{138}$

The relationship between cultural distance and mode of entry into business in foreign countries is the subject of a large research literature but has not yet been fully discerned. ${ }^{139}$ Some scholars have found that cultural distance correlated positively with high levels of home control in the entry mode (wholly owned subsidiaries). ${ }^{140}$ Others relate higher levels of cultural distance to shared

135. Harry Barkema et al., Working Abroad, Working with Others: How Firms Learn to Operate International Joint Ventures, 40 ACAD. MGMT. J. 426, 427 (1997).

136. But see infra note 179 for current efforts in this direction.

137. Bruce Kogut \& Harry Singh, The Effect of National Culture on the Choice of Entry Mode, 19 J. INT'L Bus. STUd. 411, 413-14 (1988).

138. See, e.g., Sanjeev Agarwal, Socio-Cultural Distance and the Choice of Joint Ventures: A Contingency Perspective, 2 J. Int'L MARketing 63 (1994); Harry Barkema, John Bell \& Johannes Pennings, Foreign Entry, Cultural Barriers, and Learning, 17 Strategic Mgmt. J. 151 (1996); Piero Morosini, Scott Shane \& Harbir Singh, National Cultural Distance and Crossborder Acquisition Performance, 29 J. INT'L Bus. STud. 137 (1998); Richard Fletcher \& Jenifer Bohn, The Impact of Psychic Distance on the Internationalisation of the Australian Firm, 12 J. GLOBAL MARKETING 47 (1998).

139. For a survey, see Arjen Slangen \& Jean-Franois Hennart, Cultural Distance And Foreign Direct Investment: A Comprehensive Model Explaining The Impact Of National Cultural Differences On Entry Mode Choice And Subsidiary Performance (Working Paper, 2002).

140. See, e.g., Jaideep Anand \& Andrew Delios, Location Specificity and the Transferability of Downstream Assets to Foreign Subsidiaries, 28 J. INT'L Bus. STUd. 579 (1997); Prasad 
control modes of entry (joint ventures). ${ }^{141}$ The exact answer may be contingent on the interaction between cultural distance and some additional factors. ${ }^{142}$ For the present discussion, determining the answer to this question is unnecessary. To be gleaned from this lively debate is the possibility of analyzing complex and nebulous social concepts like "cultural distance" in a fully rigorous fashion.

\section{Implications}

The above review suggests several insights gained by recent research that are directly relevant to corporate governance. The fundamental problem of corporate governance-namely, the agency problem faced by various corporate constituencies-stems from moral hazard situations, created by informational asymmetries between investors and their agents. ${ }^{143}$ Corporate governance systems utilize both legal measures and shareholding structures to mitigate these asymmetries and reduce their adverse effects. But because informational asymmetries cannot be fully eliminated, neither can the agency problem be fully resolved. When investors and corporate agents come from different cultures, the cultural distance between them may exacerbate informational asymmetries and erode the effectiveness of governance mechanisms.

The general hypothesis implied by the above-mentioned research is that basic concepts of corporate governance-including accountability, self-dealing, and fair and equitable treatment-would be related to certain value emphases and cognitive styles. These concepts probably connote fundamentally different things to Americans than to Koreans.

As a case in point, consider the independent director. Codes of corporate governance principles strongly recommend that at least a substantial number, if not a majority, of board members in public corporations should be independent. ${ }^{144}$ These codes, as well as stock exchanges' listing rules, require that sensitive board committees (for instance, remuneration committees) be dominated by independent directors. ${ }^{145}$ The exact definition of "independent" varies, but

Padmanabhan \& Kang Rae Cho, Ownership Strategy for a Foreign Affiliate: An Empirical Investigation of Japanese Firms, 36 MGMT. INT'L Rev. 45 (1996).

141. See, e.g., Kogut \& Singh, supra note 137; M. Krishna Erramilli \& C.P. Rao, Service Firms' International Entry-Mode Choice: A Modified Transaction-Cost Analysis Approach, $57 \mathrm{~J}$. MARKeTING 19 (1993).

142. See Keith Brouthers \& Lance Brouthers, Explaining the National Cultural Distance Paradox, 32 J. INT'L Bus. STUD. 177 (2001) (finding evidence for an interaction between cultural distance and investment risk).

143. See generally Andrei Shleifer \& Robert W. Vishny, A Survey of Corporate Governance, 52 J. Fin. 737 (1997).

144. For a comprehensive list of such codes and downloadable texts see the European Corporate Governance Institute's website, at http://www.ecgi.org/codes/index.htm.

145. In the wake of the Sarbanes-Oxley Act of 2002, the major national U.S. stock exchanges in early 2003 proposed listing rules that would greatly increase the role of independent directors. Thus, the NYSE proposed that (1) A majority of the company's board of directors must be independent; (2) The definition of "independent director" will be tightened; (3) The Nominating or Corporate Governance committee and the Compensation committee must be made up entirely of independent directors. See The Bank of New York, New Corporate Governance Standards for U.S. Issuers (2003), available at http://www.adrbny.com/dr_cgm_NYSE_NASDAQ.jsp. 
the ideal type of the independent director is a person who is unrelated to the company's insiders with regard to family or business ties, who will insist on transparency and accountability from senior managers, and who is capable of openly challenging the chairperson and other members of the board. Moreover, if necessary, an independent director will be willing to bring a derivative action if the interest of the company and its public shareholders requires such action. ${ }^{146}$

Can Koreans fulfill the role of independent directors as effectively as Americans, or in line with American expectations? The line of research surveyed above suggests a negative answer. A set of studies by Kim and Markus examined how values of uniqueness or conformity are manifest in mundane actions that are common in everyday life and found cultural divergence in values, beliefs, and affect. Americans preferred uniqueness, while Koreans and other East Asians preferred conformity. ${ }^{147}$ These results show that the negative connotation of conformity among Americans is a cultural construct. In East Asia, where conformity is the norm, standing out and speaking one's mind-which are cherished qualities in the United States, and are particularly sought for in outside directors-are not viewed positively.

Menon et al. compared explanations for "rogue trader" scandals in leading newspapers from a Confucian-influenced East Asian country (Japan) and from the United States. ${ }^{148}$ All cases involved multimillion dollar losses occurring in banks during the same 5-year period of 1991-1996 and incurred in connection with a mid-level manager's behavior. However, because neither the individual nor the organization fully controlled the other, blame was not definitively placed in either. The results showed that American accounts of all scandals emphasized the individual rather than the group more so than did the Asian accounts. ${ }^{149}$ In other words, while the accountability of the individual was "evident" to American observers, mitigating structural factors were not, and vice versa for the Asian commentators.

Finally, Korean views as to who may be regarded as an unrelated-and, therefore, independent-person vary greatly from American views. Koreans regard those who share the same great-great-grandfather as their relatives. As previously noted, the most common unit of bloodline-based social network is the clan, whose members identify with a shared ancestor who lived hundreds or even a thousand years ago. "Nevertheless," Han and Choe maintain, "awareness of belonging to the same clan seems enough to change interactional patterns." 150

146. See Luca Enriques, Bad Apples, Bad Oranges: A Comment from Old Europe on PostEnron Corporate Governance Reforms, 38 WAKE FoREST L. REv. 911 (2003) (providing a critical analysis of the necessary qualities expected from independent directors).

147. Heejung Kim \& Hazel Rose Markus, Deviance or Uniqueness, Harmony or Conformity? A Cultural Analysis, 77 J. Personaltry \& Soc. Psychol. 785 (1999).

148. Menon et al., supra note 126 , at $708-10$.

149. Id. at 707; see also Michael W. Morris \& Kaiping Peng, Culture and Cause: American and Chinese Attributions for Social and Physical Events, 67 J. Personal.try \& Soc. Psychol. 949 (1994).

150. Gyuseog Han \& Sug-Man Choe, Effects of Family, Region, and School Network on Interpersonal Intentions and the Analysis of Network Activities in Korea, in INDIVIDUALISM AND COLLECTIVISM: TheORY, MethoD, and Applications 213, 214 (Uichol Kim et al. eds., 1994). 
Other significant network-based identities for Koreans include regional groupings composed of people from the same hometown and school networks composed of alumni. Networks are effective in facilitating interpersonal interactions; the more networks both interactants share, the more smoothly the interaction proceeds. ${ }^{151}$

These studies suggest caution in pursuing a vigorous policy of staffing Korean boards with independent directors. A truly independent director may be considered an outsider rather than an outside director. Even if perceived as an integral part of the group of board members (and to the extent that this is so), it would be difficult for her to identify the complex cases and to ask the hard questions. This is not to say that independent directors would be worthless in Korea. There is some evidence that outside directors are associated with higher values of Korean public companies. ${ }^{152}$ Yet the trend toward giving independent directors greater pride of place is somewhat puzzling. Empirical studies in the United States thus far have not shown any significant contribution of higher board independence to corporate performance. ${ }^{153}$ The general and particular propositions stated above clearly are worthy of further investigation.

The remainder of this section discusses additional aspects of corporate governance about which cultures may differ. The focus is on the actual content of different cultural emphases more than on the degree of difference (that is, the cultural distance). Studies that find a significant contribution of cultural factors in their data (in regression analyses) effectively imply that the cultural distance was large enough to produce a noticeable variance in the observed data. Whenever cultural differences are mentioned as an obstacle to regulatory reforms one should infer that cultural distance might be involved. Concrete empirical investigation that relies explicitly on cultural distance variables is clearly warranted. ${ }^{154}$ The following section returns to this factor and connects it to informational distance in cross-listed securities.

\section{Accounting Standards and Practices}

Cross-listing studies employing various methodologies invariably indicate a potent factor in the decision to list on a foreign market is the disclosure regime that would govern the issuer in the destination market. At the heart of these disclosure regimes are the accounting principles under which issuers prepare their financial statements. These statements are public corporations' principal means of communication with their shareholders. As such, accounting disclo-

151. Id. at 218 .

152. See Bernard S. Black, Hasung Jang \& Woochan Kim, Does Corporate Governance Affect Firm Value? Evidence From Korea (Stanford Law and Economics, Olin Working Paper No. 237, 2003).

153. Benjamin E. Hermalin \& Michael S. Weisbach, Boards of Directors as an Endogenously Determined Institution (NBER, Working Paper No. 8161, 2001); Sanjai Bhagat \& Bernard Black, The Uncertain Relationship Between Board Composition and Firm Performance, 54 Bus. LAw 921 (1999).

154. With regard to the United States and Korea one may assume that the cultural distance between them is significant, at least along the Individualism/Collectivism or Autonomy/Embeddedness dimensions. 
sures are an important corporate governance tool. ${ }^{155}$ A sophisticated accounting profession with the skill to discover undisclosed self-dealing transactions and insist on proper disclosure is among the core institutions required for successful securities markets to develop. ${ }^{156}$ The findings by recent migration studies of cross-listing clustering into cultural regions and of cultural proximity affecting cross-border trading ${ }^{157}$ suggest that cultural differences may contribute to what Portes and Rey call "informational frictions." These findings beg the question whether national accounting standards reflect cultural features. Not surprisingly, the answer is that they do-or, more accurately, that they did.

Accounting is a social activity. It rests on continual judgments and decision making. In certain cases, accounting may involve ethical issues (especially in auditing activities). International accounting scholars agree that culture is a major factor among those that affect national accounting systems, including rules, practices, and institutions. ${ }^{158}$ Drawing on Hofstede's value dimensions, a seminal work by Sidney Grey set forth possible connections between national culture and accounting systems. ${ }^{159}$ For example, Grey hypothesized that a preference for secrecy in accounting would correlate with strong Uncertainty Avoidance, high Power Distance, Collectivism, and Long-term Orientation. ${ }^{160}$ Salter and Niswander found that Grey's theory is best at explaining actual financial reporting practices and that the prominent explanatory variable was Uncertainty Avoidance. Controlling for the development of financial markets and levels of taxation enhanced the strength of the findings. ${ }^{161}$ Negative relations between Uncertainty Avoidance scores and levels of disclosure were found in a number of other studies. ${ }^{162}$ Evidence further indicates that withholding information

155. See Louis Lowenstein, Financial Transparency and Corporate Governance: You Manage What You Measure, 96 ColuM. L. Rev. 1335, 1346 (1996); Mertitt B. Fox, Required Disclosure and Corporate Governance, in Comparative Corporate Governance: The State of the ART and EMERGING Research 701 (Klaus J. Hopt et al. eds., 1998).

156. See Black, supra note 9 , at 809.

157. See Pagano et al., supra note 42; Sarkissian \& Schill, supra note 44; PORTEs \& REY, supra note 48 .

158. See Helen Gernon and R.S. Olusegun Wallace, International Accounting Research: A Review of its Ecology, Contending Theories, and Methodologies, 14 J. Aсcт. LIT. 54 (1995); Harry H.E. Fechner \& Alan Kilgore, The Influence of Cultural Factors on Accounting Practice, 29 INT'L J. Acct. 265 (1994); Gerhard G. Mueller, Helen Gernon \& Gary K. Meek, Accounting: An International Perspective 10-11 (4th ed. 1997).

159. Sidney J. Gray, Towards a Theory of Cultural Influence on the Development of Accounting Systems Internationally, 24 ABACus 1 (1988). For a similar model, see Hector M. Perera, Towards a Framework to Analyze the Impact of Culture on Accounting, 24 INT'L J. ACCT. 42 (1989). See also Graeme L. Harrison \& Jill L. McKinnon, Culture and Accounting Change: A New Perspective on Corporate Reporting Regulation and Accounting Policy Formulation, 11 Acct. ORG. \& Soc'y 233 (1986). For a review of earlier efforts, see Shraddha Verma, Culture and Polmits in International Accounting: An Exploratory Framework (Working Paper, 2000).

160. Gray, supra note 159 , at 8-11.

161. Stephen B. Salter \& Frederick Niswander, Cultural Influence on the Development of Accounting Systems Internationally: A Test of Gray's [1988] Theory, 26 J. INT'L Bus. STud. 379 (1995).

162. See Michele L. Wingate, An Examination of Cultural Influence on Audit Environment, 11 Res. ACCT. REG. 115 (1997); Sidney J. Gray \& Hazel M. Vint, The Impact of Culture on Accounting Disclosures: Some International Evidence, 2 AsIA-PAC. J. AccT. 33 (1995); Timothy S. Doupnik \& 
from investors in high Uncertainty Avoidance countries benefits companies through lower litigation. ${ }^{163}$

The intensifying cross-listing trend during the 1990s has underscored the fact that international diversity in accounting systems has imposed heavy transaction costs on issuers who have wanted to tap foreign markets, due to the need to prepare a different set of financial statements according to each market's accounting regime. It has been shown, however, that the reconciliation of accounting data to U.S. generally accepted accounting principles (GAAP) required under Form $20-\mathrm{F}$ was value-relevant. ${ }^{164}$ For over a decade, U.S. GAAP were thus praised by SEC officials as a central component of the greater investor protection provided by American stock markets. Yet, these principles were also blamed by NYSE officials for deterring potential issuers from bringing more business to U.S. stock exchanges. ${ }^{165}$ During the late 1990s, the SEC clashed with the International Accounting Standards Committee (IASC) over the ultimate content and stringency of the International Accounting Standards (IAS) that the IASC was developing. The confrontational interaction with the IASC intended to ensure that the U.S. markets were not put at a competitive disadvantage vis-à-vis non-U.S. markets. ${ }^{166}$

The resulting set of thirty core IASs eventually produced by IASC and endorsed by the International Organization of Securities Commissions $(\mathrm{IOSCO})^{167}$ - though not yet by the SEC-is said to be very close to U.S. GAAP. ${ }^{168}$ The world is nearing a point in which the larger part of disclosure regulation will not exhibit cross-national diversity, as comparability of financial statements will be ensured. ${ }^{169}$

Stephen B. Salter, External Environment, Culture, and Accounting Practice: A Preliminary Test of a General Model of International Accounting Development, 30 INT'L J. AccT. 189 (1995).

163. See Wingate, supra note 161.

164. See Eli Amir, Trevor S. Harris \& Elizabeth K. Venuti, A Comparison of the Value-Relevance of U.S. versus Non-U.S. GAAP Accounting Measures Using Form 2O-F Reconciliations, $31 \mathrm{~J}$. ACCT. REs. 230 (1993).

165. See, e.g., Richard C. Breeden, Foreign Companies and U.S. Securities Markets in a Time of Economic Transformation, 17 FordhaM INT'L L. J. 77 (1994); James L. Cochrane, Are U.S. Regulatory Requirements for Foreign Firms Appropriate?, 17 FordHAM INT'L L. J. S58 (1994); see also Carol A. Frost \& Mark H. Lang, Foreign Companies and U.S. Securities Markets: Financial Reporting Policy Issues and Suggestions for Research, 10 Accr. HoRIzons 95 (1996) (reporting that that the SEC's financial reporting requirements may deter foreign firms from offering their securities on U.S. markets); William J. Baumol \& Burton G. Malkiel, Redundant Regulation of Foreign Security Trading and U.S. Competitiveness, in Modernizing U.S. SeCurITIES Regulation 39 (Keneth Lehn \& Robert Kamphius eds., 1992).

166. See Amir N. Licht, Games Commissions Play: $2 \times 2$ Games of International Securities Regulation, 24 YALE J. INT'L L. 61 (1999).

167. IOSCO, IASC Standards - Assessment Report (2000).

168. See Donna L. Street et al., Assessing the Acceptability of International Accounting Standards in the US: An Empirical Study of the Materiality of US GAAP Reconciliations by Non-US Companies Complying with IASC Standards, 35 INT'L J. ACCT. 27 (2000) (finding narrowing differences between U.S. GAAP and IAS and suggesting that the SEC should consider accepting IAS standards without condition).

169. As regards the bonding-or-avoiding question, competition among stock markets may not any more revolve around disclosure regulation. In theory, this would pronounce the end of the piggybacking race as it would render the bonding (and the avoiding) rationale redundant. Competi- 
Empirical research shows that the imprint of national cultures on accounting systems still looms, however. As the trend of accounting standard harmonization gains momentum, culturally-related differences that in the 1990 s were discernable in formal accounting rules have become less visible. The adoption of the IAS surely increases the amount of information available to public investors ${ }^{170}$ and it can therefore mitigate moral hazard in issuers who seek a foreign listing. If regulators require IAS-based disclosure from domestic issuers as well, then differences among national regimes would further diminish. Yet even disclosures that comply with IAS are prepared by professionals in the issuer's home country. To the extent that the issuer's home country traditionally did not require the fullest disclosure, the problem becomes one of enforcing the new rules rather than requiring disclosure.

A study of accounting disclosures by issuers who complied with IAS shows that de facto compliance with IAS is greater for issuers with U.S. listings or filings. This highlights the significance of enforcement of any disclosure regime that would govern issuers. ${ }^{171}$ The accounting professionals entrusted with this task are the auditors. But formal harmonization reforms may have little impact on auditing practices. Thus, differences in auditing practices were found between British auditors and German ones, notwithstanding a European Union Directive that established the "true and fair view" as a general auditing standard. ${ }^{172}$

Arnold et al. recently examined differences in materiality estimates among experienced senior auditors in the (then) big-six accounting firms in Europe. Subjects were asked to estimate the materiality of discrepancies in financial statements of a client whose integrity was rated as high or low. ${ }^{173}$ Although there are conventions and formal guidelines for auditors governing materiality thresholds, significant differences were found among auditors in their materiality judgments. Uncertainty Avoidance emerged as the most powerful explanatory variable for these differences; in high Uncertainty Avoidance societies, auditors might expand the limits of the materiality estimates so that remaining errors are not deemed material. ${ }^{174}$

The materiality of informational items is perhaps the single most important issue in securities regulation. Materiality is the yardstick with which the scope

tion would focus on liquidity, clearance and settlement, and similar issues of little concern to lawyers. Such a conclusion would be premature, however, as shown in the text.

170. But see Norlin G. Rueschhoff \& C. David Strupeck, Equity Returns: Local GAAP versus U.S. GAAP For Foreign Issuers From Developing Countries, 33 J. INT'L ACCT. 377 (1998) (differences in accounting principles cause extreme variations in reported net income, stockholders' equity, and equity returns for some developing countries, notwithstanding reconciliation with U.S. GAAP).

171. See Donna L. Street \& Stephanie M. Bryant, Disclosure Level and Compliance with IASs: A Comparison of Companies With and Without U.S. Listings and Filings, 35 INT'L J. ACCT. 305 (2000).

172. See Carol A. Frost \& Kurt P. Ramin, International Auditing Differences, 181 J. Acr'v. 62 (1996).

173. See Donald F. Arnold Sr., Richard A. Bernardi \& Presha E. Neidermeyer, The Association Between European Materiality Estimates and Client Integrity, National Culture, and Litigation, 36 INT'L J. AccT. 459 (2001).

174. Id. at $472-76$. 
of required disclosure is determined and hence the test under which cases of misrepresentation, fraud, and insider trading are decided. ${ }^{175}$ Arnold et al.'s study implies that at the most sensitive junctions of judgment on corporate disclosure, the people in charge of guaranteeing the quality of disclosure are affected by their cultural values. No matter how harmonized (or reconciled) the disclosures of a cross-listed foreign issuer are as a matter of form, these disclosures will differ systematically from a similar disclosure of a domestic issuer. Note that Arnold et al.'s subjects were top-of-the-line auditors, working in local branches of American firms under highly uniform standards. It is plausible to assume that the disclosures of issuers who use purely local accounting professionals or are located in non-Western countries will exhibit even stronger cultural biases.

In the case of Korea, several reforms mandated by the IMF related to accounting issues to improve public shareholders' protection. These reforms included convergence toward the IAS, preparation of special combined statements for the chaebols, and nomination of external auditors in listed firms. Jong-Seo Choi provides a piercing account of Korea's accounting system as one that prefers secrecy and favors chaebols' owner-managers-consistent with Korea's cultural profile of a Confucian country. ${ }^{176}$ Regarding the degree to which the reforms might have changed this system, Choi correctly observes that cultures exhibit high resilience to change but that external shocks could induce change. Yet the 1997 crisis apparently has not been a shock of sufficient magnitude, as most of these numerous reforms remain on paper. They have had little impact on actual practice, in accounting as well as in corporate governance. Summarizing this view, Choi concludes,

[D]espite accounting systems changes after the 1997 financial crisis in Korea, the accounting cultural environment still remains qualitatively not very much different from what it used to be before the crisis .... [T] he motives for favoring accounting flexibility and secrecy still remain alive despite all the institutional efforts to enhance transparency and uniformity. ${ }^{177}$

\section{Legal Rules and Infrastructure}

As compared with the treatment of cultural influences in accounting research, legal literature on corporate governance lags far behind. Drawing on

175. See, e.g., James D. Cox, Robert W. Hillman \& Donald C. Langevoort, Securities Regulation: Cases and Materials $39-40$ (3rd ed. 2001); Louis Loss \& Joel Seligman, Fundamentals of Securities Regulation 473 (3rd ed. 1995). For the SEC's position, see Securtties and Exchange Commission, Materiality, Staff Accounting Bulletin SAB No. 99 (1999), available at http://www.sec.gov/interps/account/sab99.htm.

176. ChoI, supra note 119, at 10-11; see also Youngok Kim, Determinants of Financial Reporting System: The Case Of South Korea (Working Paper, 2001) (arguing that the "deeprooted Confucian values have significantly affected Korea's economic and financial reporting system").

177. Chor, supra note 119 , at 25 . Choi further reports the results of a survey of practicing Korean accountants that confirm this conclusion. A vast majority of the respondents confirmed that accounting conventions of secrecy and flexibility ("window dressing") have not changed and that auditor independence was lacking (citing Jong-Seo Choi, Evaluating the Accounting Reforms in Korea After the 1997 Economic Crisis, 1 J. KOREAN ECON. 1 (2001)). 
different disciplines, some works have included calls for considering cultural aspects. ${ }^{178}$ Finance scholars are also starting to show interest in investigating these issues. ${ }^{179}$ A recent collaborative study with my colleagues Goldschmidt and Schwartz finds that La Porta et al.'s indices of investor protection correlate with cultural orientations toward low Harmony and low Uncertainty Avoidance, possibly in relation with countries' heritage of British rule. ${ }^{180}$ Similar correlations are found for measures of formalism in civil litigation rules. ${ }^{181}$ These findings are consistent with the view that nations vary in their inclination toward reconciling conflicting economic interests through volatile, confrontational litigation. ${ }^{182}$

In a separate study, ${ }^{183}$ we found that levels of perceived legality (rule of law), non-corruption, and democratic accountability strongly and systematically correlate with higher Individualism and lower Power Distance in Hofstede's model. Better governance norms also correlate with higher Autonomy and Egalitarianism in Schwartz's model. These are the cultural values that Confucian countries tend to $d e$-emphasize. In a regional comparison, Far Eastern countries on average score significantly lower on all measures of governance relative to English-speaking and West European countries. ${ }^{184}$

The societal emphases reflected in these findings are compatible with diametrical views about the rule of law as a desirable basis of social order that were expounded generations ago by Socrates and Confucius. ${ }^{185}$ At least in countries with a strong Confucian heritage, the cultural infrastructure calls on people to seek guidance for conducting their personal life and social interactions in

178. See Milhaupt, supra note 105 (political economy); Fanto, supra note 104 (political economy); Licht, supra note 76 (cross-cultural psychology). See generally Douglas M. Branson, The Very Uncertain Prospect of 'Global' Convergence in Corporate Governance, 34 CORNELL INT'L L.J. 321 (2001); Teemu Ruskola, Conceptualizing Corporations and Kinship: Comparative Law and Development Theory in a Chinese Perspective, 52 Stan. L. REv. 1599 (2000).

179. See Stulz \& Williamson, supra note 102; Thorsten Beck, Asli Demirguc-Kunt \& Ross Levine, Law, Endowments, and Finance, J. Fin. Econ. (forthcoming 2004).

180. Amir N. Licht, et al, Culture, Law, And Corporate Governance, InT'L Rev. L. \& Econ. (forthcoming 2004).

181. Id. The measures of formalism in civil litigation rules were drawn from Simeon Djankov et al., Courts: The Lex Mundi Project, 118 Q. J. Econ. 453 (2003).

182. See Oscar G. Chase, Legal Processes and National Culture, 5 Cardozo J. INT'L \& Comp. L. 1, 17-18 (1997). See generally Mirjan Damaska, The Faces of Justice and State Authority: A Comparative Approach to the Legal Process (1974-1975).

183. Amir N. Licht, Chanan Goldschmidt \& Shalom H. Schwartz, Culture Rules: The Foundations of the Rule of Law and Other Norms of Governance (Working Paper, 2003).

184. South Korea is not included in the sample used in this study.

185. Socrates's refusal to escape from jail after the city of Athens sentenced him to death is often presented as the classic exposition of arguments for the duty to obey the law and, generally, for the importance of the rule of law for social order. At about the same time, in equally powerful terms Confucius derided the rule of law as a means for establishing social order in China. On Socrates, see M.B.E. Smith, Is There a Prima Facie Obligation to Obey the Law?, 82 Y ALE L.J. 950 (1972-1973); Philip Soper, Another Look at the Crito, 41 AM. J. JuRIS. 103 (1996); Frances Olsen, Socrates on Legal Obligation: Legitimation Theory and Civil Disobedience, 18 GA. L. REv. 929 (1984). On Confucius, see William P. Alford, On the Limits of 'Grand Theory' in Comparative Law, 61 Wash. L. REv. 945 (1986); Albert H.Y. Chen, Toward a Legal Enlightenment: Discussions in Contemporary China on the Rule of Law, 17 UCLA PAC. BASIN L.J. 125 (1999-2000). 
sources other than the law. ${ }^{186}$ As a result, reforms in governance systems that rely on legislative amendments are bound to face serious challenges in their implementation phase. A fortiori, efforts to upgrade a Korean issuer's corporate governance by adding an external layer of foreign rules and regulations through cross-listing-beneficial as they might be-are likely to meet even greater hurdles. To the issuer's management, accountants, and similar parties, the foreignness of such rules and regulations is not only technical, but fundamental.

\section{Policy Implications}

This section has made considerable forays beyond the areas usually covered in discussions of corporate governance and securities regulation. The immediate motivation for this was the recently-gained recognition that standard economic and financial factors cannot fully explain the observed patterns in cross-listings - in particular, the weakness of evidence in support of the bonding hypothesis. In the present context, the findings surveyed in this section provide concrete content to the somewhat fuzzy notions of familiarity, foreignness, and cultural distance among nations, securities markets, issuers, and investors.

These findings have direct implications for policy-makers and business people. Bernard Black has noted that in order to develop well-functioning securities markets, a country would need to ensure that a host of appropriate legal, regulatory, professional, and cultural elements are in place. ${ }^{187}$ This elaborate social infrastructure is needed for combating insiders' resourcefulness in illegitimately deriving private benefits from public corporations. Cross-listing on a well-regulated market would serve as a short-cut for issuers interested in selfimproving their corporate governance beyond the level provided by their home country's regime. This piggybacking strategy relies on an implicit assumption that the destination-market's regime would mesh smoothly with the issuer's existing regime. To use the legal plug-in metaphor, the plug-in regulatory components provided even by the better-regulated destination markets do not add much force to issuers' governance systems (and in some cases actually could downgrade them). ${ }^{188}$ This section has shown that differences among nations may lead to regulatory components failing to plug-in into foreign issuers' governance systems. With greater distance-geographical, cultural, or other-between an issuer's origin and destination markets come greater challenges to utilizing the destination market's regulatory regime.

Yet the policy implications of cultural distance go much deeper than pointing to limits to the usefulness of cross-listing for corporate governance improvement. Nor would one argue in earnest that foreign legal elements can be adopted by another legal system without at least some adaptation. The theory and preliminary evidence on cultural emphases and cultural distance contribute to the analysis and design of legal reform by pointing out the magnitude of

186. For a general insightful discussion of the current situation in Korea, see Chaihark Hahm, Law, Culture, and the Politics of Confucianism, 16 Colum. J. Asian L. 253 (2003).

187. See Black, supra note 9.

188. Licht, Bonding or Avoiding, supra note 10. 
potential resistance by receiving countries, or corporations, to foreign legal elements. Cultural orientations represent general societal emphases that are deeply ingrained in the functioning of major societal institutions, in widespread practices, in symbols and traditions, and, through adaptation and socialization, in the values of individuals. The theories and data that underlie the present discussion suggest that cultural orientations change slowly over time spans of decades and centuries. As a result, cultural value emphases may preserve and perpetuate the imprint of ancient intellectual legacies and historical initial conditions. ${ }^{189}$

The foregoing discussion leads to a more fundamental issue. Various rationales underlie the predominance of Anglo-American features in current blueprints for reform in corporate governance and securities regulation regimes. The dominance of American and British institutional investors in the global securities market creates a demand for familiar features, which are hopefully effective for minority investors like them. In part, this dominance may be a derivative of the United States' prominence in international organizations like the World Bank and the IMF. In part, it is supported by the evidence cited in the introduction. ${ }^{190}$ Yet as we have seen, the implementation of these models in other countries faces considerable obstacles. Furthermore, in the wake of the 2002 wave of scandals in the United States, this system no longer is perceived as optimal.

The architects of corporate governance reform may want to consider the idea of culturally compatible governance. For instance, Korea has done quite well with its own version of corporate governance, based on an amalgam of imported legal elements and local practices. Although the system collapsed, it also rebounded, most likely thanks to its own qualities more than to the reforms in law and accounting principles. It is true that the Korean corporate governance system could be improved-and must improve in order to compete in global markets. The far-reaching reliance on American models may bring about some improvement. But Korean reformers could devise better corporate governance that draws on the country's huge social capital that its cultural endowment embodies.

Indeed, Koreans today seem to treat their Confucian heritage with ambivalence. ${ }^{191}$ In the current political ideological landscape in Korea, people who champion ideals of democracy would also argue that the Confucian heritage still found in Korean society has no legitimate space. "According to this conception, Confucianism represented hierarchy, feudalism, elitism, and male domination, and an enlightened, democratic, and progressive Korean nation had no use for such things." 192 Yet by ignoring the potential value of this endowment the re-

189. See Licht, et al., supra note 180, Modernization, Cultural Change, and the Persistance of Traditional Values, 65 Am. SociologicAl Rev. 19 (2000); Shalom H. Schwartz \& Maria Ros, Values in the West: A Theoretical and Empirical Challenge to the Individualism-Collectivism Cultural Dimension, 1 WoRld PsYchol. 93 (1995).

190. For a comprehensive analysis, see Marco Becht, Patrick Bolton \& Ailsa Roell, Corporate Governance and Control (NBER, Working Paper No. 9371, 2002).

191. Hahm, supra note 186 , at $66-267,277,297-98$.

192. Id. at 298. 
forms resemble an attempt to write-off Korea's Confucian heritage as an economically productive asset. Designing a culturally-compatible governance model that would leverage this social capital and put it to modern productive use exceeds the scope of this article and is left to future research.

III.

\section{Informational Distance Revisited}

The research evidence showing that informational distance is a major determinant in cross-border listing and trading is related by researchers to cultural affinities between countries, as expressed with language, common colonial heritage and so on. This view is closely related to the conceptual definition of cultural distance that is based on the need for knowledge, on the one hand, and barriers to knowledge flow on the other hand. This section adds another perspective to question the governance-improving effect of cross-listing. Crosslisting opens new avenues for corporate insiders to take advantage of public shareholders by trading on inside information. Instead of ameliorating the adverse effects of moral hazard due to information asymmetries, cross-listing may in fact exacerbate them. Recalling that cross-listing is supposed to facilitate the flow of information between firms and investors who are located in different countries, cultural distance can either facilitate or hinder this effect. The greater the cultural distance between home and host countries is, the hypothesis goes, the larger is the informational asymmetry between them and the more difficult it is to close this informational gap through cross-listing.

Two strands of research in international finance bear on the relevant issues, namely, asset pricing in international securities markets and market microstructure. Both topics are technical and relatively less accessible, yet they entail policy implications in the present context and are discussed in turn.

\section{A. International Information Asymmetry}

A well-documented phenomenon in international securities markets is the home bias. ${ }^{193}$ Basic financial prudence calls for diversifying idiosyncratic risks in investors' portfolios to the extent possible. Such diversification would also include international diversification so as to minimize country-specific risks. ${ }^{194}$ Yet investors exhibit a home bias by overweighing the domestic market in their

193. For literature reviews on home bias, see G. Andrew Karolyi \& Rene M. Stulz, Are Financial Assets Priced Locally or Globally?, in The HANDBOOK of THE Economic of FinanCe (George Constantinides, Milton Harris \& Rene M. Stulz eds., forthcoming) (NBER, Working Paper No. 8994, 2002); Karen K. Lewis, Trying to Explain Home Bias in Equities and Consumption, $37 \mathrm{~J}$. ECon. LrT. 571 (1999). Seminal works on the home bias include Jun-Koo Kang and Rene M. Stulz, Why Is There a Home Bias? An Analysis of Foreign Porffolio Equity Ownership in Japan, $46 \mathrm{~J}$. FIN. Econ. 3 (1997); Linda L. Tesar \& Ingrid M. Werner, Home Bias and High Turnover, 14 J. INT'L MONEY \& Fin, 467 (1995); Ian Cooper \& Evi Kaplanis, Home Bias in Equity Portfolios, Inflation Hedging, and International Capital Market Equilibrium, 7 REv. Fin. STuD. 45 (1994); Kenneth R. French \& James M. Poterba, Investor Diversification and International Equity Markets, 81 AM. ECON. REv. 222 (1991).

194. See supra note 19. 
portfolios. This phenomenon persists despite the collapse of many barriers that previously segmented securities markets. ${ }^{195}$ As securities markets become more integrated, researchers pay more attention to information asymmetries among market players in an attempt to explain the home bias and other phenomena, which show that location matters.

Major advances in telecommunication technology notwithstanding, geographical proximity to information sources still confers substantial benefits on those closer to such sources even at the domestic level. ${ }^{196}$ This informational advantage encourages investors to prefer stocks that are closer to them, thus supporting a home bias at the domestic level. ${ }^{197}$ At the international level, the picture is more complicated. It may be more accurate to refer to an "informational distance" in this context rather than just geographical distance. Several factors may affect firms' informational distance from investors. Firstly, geographical distance at the international level operates as at the domestic level in putting more distant investors at a relative disadvantage. ${ }^{198}$ In a similar vein, but based on other aspects of foreignness, it has been shown that language and

195. But see Alan G. Ahearne, et al., Information Costs and Home Bias: An Analysis of U.S. Holdings of Foreign EquTries (Working Paper, Federal Reserve Board, 2000) (arguing that transaction costs associated with investment in foreign stocks, while economically insignificant, do exhibit a statistically significant relation to U.S. holdings of foreign stocks); SOHNKE M. BARtram \& Gunter Dufey, International Portfolio Investment: Theory, Evidence, And InstiTUTIONAL FRAMEWORK (Working Paper, 2001), available at http://papers.ssrn.com/paper.taf? abstract_id=270196 (arguing that there are many institutional constraints and barriers for international portfolio investment, significant among them a host of tax issues, which support the case for internationally segmented securities markets). See also Alexander Michaelides, International Portfolio Choice, Liquidity Constraints and the Home Equity Blas Puzzle (CEPR, Discussion Paper No. 3066, 2001), available at http://papers.ssrn.com/paper.taf?abstract_id=292311 (presenting a model in which the benefits of international diversification are limited because consumption fluctuations can be smoothed with a small amount of buffer stock saving, while exchange rate risk makes foreign investments less appealing to risk averse investors).

196. See Harald Hau, Location Matters: An Examination of Trading Profits, 56 J. Fin. 1959 (2001) (arguing that distance from Frankfurt advantages proprietary traders trading in German stocks).

197. See Joshua D. Coval \& Tobias J. Moskowitz, Home Bias at Home: Local Equity Preference in Domestic Portfolios, 54 J. FIN. 2045 (1999) (showing that the weight of U.S. stocks in U.S. mutual funds is negatively related to the distance between the location of the fund and location of firms' headquarters); Joshua D. Coval \& Tobias J. Moskowitz, The Geography of Investment: Informed Trading and Asset Prices, 109 J. PoL. Econ 811 (2001) (finding mutual fund managers do better with stocks of firms located more closely to where the fund is located); see also Tom Arnold, Phil Hersch, J. Harold Mulherin \& Jeff Netter, Merging Markets, 54 J. Fin. 1083 (1999) (demonstrating that U.S. firms in the early twentieth century tended to locate on exchanges near company headquarters).

198. See Harald Hau, Geographic Patters of Trading Profitability, in Xetra, 45 EUR. Econ. REv. 757 (2001) (finding foreign traders underperform at intraday, intraweek, and intraquarter trading horizons, confirming the hypothesis of financial market segmentation due to international information barriers); Mark Grinblatt \& Matti Keloharju, The Investment Behavior and Performance of Various Investor Types: A Study of Finland's Unique Data Set, 55 J. Fin. Econ. 43 (2000); Mark Grinblatt \& Matti Keloharju, How Distance, Language, and Culture Influence Stockholdings and Trades, 56 J. FIN. 1053 (2001) [hereinafter Distance, Language, Culture] (in a sample of Finnish stocks, investors are more likely to hold, buy and sell the stocks of Finnish firms that are located close to the investor); see also R.K. Shukla \& G.B. Van Inwegen, Do Locals Perform Better than Foreigners? An Analysis of UK and US Mutual Fund Managers, 47 J. EcoN. Bus. 241 (1995) (demonstrating UK money managers underperform American money managers in picking U.S. stocks). 
cultural differences (loosely defined) correlate positively with investors' preferences for particular stocks. ${ }^{199}$ The quality of corporate governance in firms' home country may also affect the degree of home bias. ${ }^{200}$ On the other hand, since foreign investors tend to be large institutions they are more likely to have better resources for managing their portfolios and, generally, be more sophisticated. ${ }^{201}$

Choe, Kho, and Stulz examined whether domestic investors have an information advantage over foreign investors with regard to individual stocks traded on the Korean Stock Exchange from end-1996 to end-1998. ${ }^{202}$ Foreign investors were found to buy at significantly higher prices and sell at significantly lower prices than domestic individuals for medium and large trades. Foreign institutions are less disadvantaged relative to domestic institutions than relative to individual investors. Moreover, foreign investors are significant net buyers before a negative abnormal return event and significant net sellers before a positive abnormal return event. Whereas foreigners do not trade ahead of the event day, it appears that domestic investors do. Foreign investors also trade at worse prices than domestic individuals typically do. ${ }^{203}$ These and additional findings suggest that individual Korean investors systematically take advantage of foreign investors. Although the magnitude of this disadvantage may not be substantial for long-term institutional investors, potential buyers of Korean ADRs will be alarmed by these findings.

199. See Portes \& ReY, supra note 48; Grinblatt \& Keloharju, Distance, Language, Culture, supra note 197 (investors are more likely to hold, buy and sell the stocks of Finnish firms that communicate in the investor's native tongue, and that have chief executives of the same cultural background); see also Dusan Isakov \& Frederic Sonney, Are Practitioners Right? On the Relative Importance of Industrial Factors in International Stock Returns (Working Paper, 2002), available at http://papers.ssrn.com/paper.taf?abstract_id=301536 (in a sample of more than 4000 stocks quoted in 20 countries. finding that on average the country effect dominates industrial effects over stock returns during 1997-2000).

200. See Rene M. Stulz, Magnus Dahlquist, Lee Pinkowitz \& Rohan Williamson, Corporate Governance, Investor Protection, and the Home Bias (Working Paper, 2002) (arguing that the prevalence of closely held firms in countries with poor investor protection explains part of the home bias of U.S. investors). It is not entirely clear what causal factors drive the results reported in this study. While it makes sense for investors to avoid stocks of firms whose insiders are more likely to exploit public shareholders, this increased likelihood should be reflected-at least roughly-in the stocks' prices. The rationale for portfolio diversification is not to buy only "good" stocks; "bad" stocks from foreign countries should be a valuable addition to a portfolio provided they are discounted appropriately. A more fundamental factor may prevent foreign issuers from being able to correctly price these stocks. Cultural differences seem like a good candidate for such a factor-a conjecture that deserves further analysis.

201. See Magnus Dahlquist \& Goran Robertsson, Direct Foreign Ownership, Institutional Investors, and Firm Characteristics, 59 J. Fin. Econ. 413 (2001) (arguing that the bias in foreign holdings is more a bias in the type of foreign investor, as international investing is primarily done by institutions, than due to preferences in foreign stock characteristics); Mark Seasholes, SMart ForEIGN TRAders In EMERGING MARKeTs (Working Paper, 2000) (foreign investors buy (sell) ahead of good (bad) earnings announcements in Taiwan while local investors do the opposite, suggesting that the foreigners are more sophisticated).

202. See Hyuk Choe, Bong-Chan Kho \& Rene M. Stulz, Do Domestic Investors Have More Valuable Information About Individual Stocks Than Foreign Investors? (NBER, Working Paper No. 8073, 2001).

203. Id. at 2-4. 


\section{B. Dominant Markets and Informed Trading}

Cross-listing can affect the home bias by mitigating some aspects of foreign stocks' informational distance. For example, U.S. exchange-listed foreign firms report in English and reconcile their financial statements to U.S. GAAP. ${ }^{204}$ American investors may thus consider these firms more familiar and increase their holdings in them. ${ }^{205}$ Yet, as it brings foreign stocks closer to investors, cross-listing also brings innocent (or at least less-informed) investors closer to unscrupulous insiders. Cross-listing may thus make investors in host markets more likely to get exploited by better-informed traders. By connecting the home market with the foreign host market, cross-listing increases the opportunities for insiders to profit from private information. This argument was presented in detail elsewhere based on then available theory and evidence. ${ }^{206}$ More recent research informs this discussion and the policy implications stemming from it.

A common wisdom in the theory of market structure used to be that stock markets are bound to consolidate. ${ }^{207}$ The underlying logic of this prediction was that market liquidity engenders positive network externalities and therefore "liquidity attracts liquidity."208 Greater liquidity improves the ability of markets to perform their primary function of facilitating trading by matching buyers and sellers and enabling them to effect trades on the best possible terms. Therefore, one big market would be better than two small ones. ${ }^{209}$

Although stock exchange consolidation is already under way and is likely to continue to some degree, ${ }^{210}$ it is doubtful that market fragmentation will ever disappear. Even the most sophisticated markets, such as the NYSE, exhibit fragmentation features both in time (through continuous trading) and in space (the "upstairs" market). It seems that fragmentation helps the market to function by catering to participants with special needs. ${ }^{211}$ Lipson presents a model that extends this logic to international markets in cross-listed stocks. ${ }^{212}$ In this respect, financial factors will always be second to national support for the mainte-

204. As opposed to foreign firms that only use Level I ADRs.

205. See AHEARNE ET AL., supra note 1954 (showing that the portion of a country's market that has a public U.S. listing is a major determinant of a country's weight in U.S. investors' portfolios).

206. See Licht, supra note 8, at 590-602.

207. For a review, see Norman S. Poser, The Stock Exchanges of the United States and Europe: Automation, Globalization, and Consolidation, 22 U. PA. J. INT'L EcoN. L. 497 (2001).

208. See, e.g., Carmine Di Noia, Competition and Integration Among Stock Exchanges in Europe: Network Effects, Implicit Mergers and Regulatory Considerations, 7 Eur. Fin. Mgmt. 39 (2001); Alberto Cybo-Ottone, Carmine Di Noia, \& Maurizio Murgia, Recent Developments in the Structure of Securities Markets, in Brookings-Wharton Papers on Financial Services 2000223 (Robert Litan \& Anthony Santomero eds., 2000).

209. This point is also the starting point for Coffee's theory on bonding by cross-listing. Coffee, supra note 32, at 3-4. The following analysis thus bears on this theory as well.

210. See Amir N. Licht, Stock Exchange Mobility, Unilateral Regulation, and the Privatization of Securities Regulation, 41 VA. J. Int'L L. 583 (2001); Stun Claessens, Daniela Kinngebiel \& Sergio L. Schmukler, Explaining the Migration of Stocks from Emerging Economies to International Centers (World Bank, Working Paper, 2002).

211. See Ananth Madhavan, Market Microstructure: A Survey, 3 J. Fin. Markets 205 (2000).

212. See Marc L. Lipson, Fragmentation, Consolidation and Competition for listings (Working Paper, 2002). 
nance of a national stock market. With regard to policy implications and regulatory concerns, attention should be better paid to the serious issues that arise in the current situation.

When a stock is cross-listed on more than one market, constant arbitrage activity takes place between these markets, causing the price of the stock to behave as if it is generated by a single process. ${ }^{213}$ Yet these markets do not have an equal role in the price formation process. In practice, one market functions as the dominant market in that it tends to lead the movement of prices. The other markets function as satellites, constantly chasing price movements in the dominant market and occasionally contributing to price formation. There is now ample evidence showing that the home markets of cross-listed firms dominate the price formation process. ${ }^{214}$ This is consistent with the evidence on informational asymmetries in trading and in holdings of foreign securities that favor the home countries.

The integrity of the price discovery process is a matter of great import. In its seminal decision in Basic Inc. v. Levinson, the U.S. Supreme Court held that "[a]n investor who buys or sells stock at the price set by the market does so in reliance on the integrity of that price." 215 This presumption of reliance rests on an underlying assumption about the informational efficiency of the major markets in the United States. It also relies on the assumption that all material information concerning the issuer had been disclosed. Insiders are prohibited from trading on material non-public information. ${ }^{216}$ In practice, American insiders do trade on inside information, ${ }^{217}$ but the levels of insider trading in other countries appear to be considerably higher. ${ }^{218}$

213. For a review of studies on international arbitrage and the "law of one price" in cross-listed stocks, see Licht, supra note 8 , at 590-96.

214. See Shmuel Hauser, Yael Tanchuma \& Uzi Yaari, Intemational Transfer of Pricing Information Between Dually Listed Stocks, 21 J. FiN. Res. 139 (1998); Kenneth A. Froot \& Emil Dabora, How Are Stock Prices Affected By The Location Of Trade?, 53 J. Fin ECon. 189 (1999); ChEOL S. Eun \& Sanjiv Sabherwal, Price Discovery for Internationally Traded Securities: Evidence From the U.S.-Listed Canadian Stocks (Working Paper, 2000); Joachim Grammig, Michael Melvin \& Christian Schlag, Price Discovery In International Equity Trading (Working Paper, 2001); Magueye Dia, The Allocation Of Liquidity and Price Discovery across Exchanges after Multinational Mergers (Working Paper, 2001). The host market may play a more significant role in price discovery if substantial shareholding develops in the host country, or when the economies of the two countries are highly integrated in general, as is the case for Canada and the U.S. See Eun \& SABHERwal, supra this note.

215. 485 U.S. 224, 247 (1988). The Court commented further that "Congress expressly relied on the premise that securities markets are affected by information, and enacted legislation to facilitate an investor's reliance on the integrity of those markets." Id. at 246.

216. The scope of persons potentially liable for insider trading under American law is ambiguous, but there is no doubt that company insiders are subject to this prohibition. For a discussion see Richard W. Painter, Kimberly D. Krawiec \& Cynthia A. Williams, Don't Ask, Just Tell: Insider Trading After United States v. O'Hagan, 84 VA. L. Rev. 153 (1998).

217. See, e.g., Lisa Muelbroek, An Empirical Analysis of Illegal Insider Trading, 47 J. Fin. 1661 (1992) (insiders profit from insider trading); Asjeet S. Lamba \& Walayet A. Khan, Exchange Listings and Delistings: The Role of Insider Information and Insider Trading, 3 J. FIN. REs. 131 (1999) (finding insiders act on their private information before exchange listings and delistings).

218. See Utpal Bhattacharya \& Hazem Daouk, The World Price Of Insider Trading, 57 J. Fin. 75 (2002); Olesya V. Grishchenko, Lubomir P. Litov and Jianping Mei, Measuring Private Information Trading In EMERGING MARKets (Working Paper, 2002) (finding strong evidence of 
How does cross-listing affect the incidence of insider trading in the issuer's stock? Market structure scholars previously differed on this point. ${ }^{219}$ To see the problem, consider a simple setting first. When one party to a transaction has superior information, the other, less-informed party is bound to lose. Theoretical models of market trading usually consider an informed trader, a market professional, and an uninformed trader. The latter trader is sometimes referred to as a "noise trader," since she lacks actual information on firm value, or as a "liquidity trader," since she may be motivated by liquidity considerations. ${ }^{220} \mathrm{Li}$ quidity traders are the constituency that is typically being exploited by informed traders. However, market professionals too may find themselves facing an informed trader without knowing it. In a single market, these professionals will respond by adjusting their buy and sell prices (or quotes) to the likelihood of transacting with an informed trader.

The next step is to move to a multi-market environment. In this setting, two or more markets compete with each other for the flow of order. Beyond lowering transaction costs, markets could also compete over their level of integrity. Two strands of arguments can be identified on this issue. Chowdhry and Nanda advanced a theoretical model in which market makers divulge trading information more fully, by making the trading process more transparent, in order to discourage trading by informed traders or insiders. ${ }^{221}$ The competitive dynamics that emerges is for the "cleaner" market, as market makers "race-for-the-top" in cracking down on insider trading. The more stringent market succeeds in attracting most of the trading.

Another line of studies reaches opposite conclusions. Madhavan presented a model in which in addition to informed and uninformed traders, there are also large liquidity traders (such as institutional investors) who would like to work their positions gradually into the market and split them between markets. ${ }^{222}$ In this setting, fragmentation and lesser transparency is the equilibrium, and there is no race for the top. Consequently, informed traders can also conceal their trades more easily. Finally, a recent study by Nuno Martins presents a theoretical model in which information asymmetries between investors drive the foreign listing decision. Strikingly, the model predicts that as information asymmetries increase, an international listing will benefit the domestic informed traders. With cross-listing of the firm, domestic informed traders increase the volume of trading as they now have additional means to take advantage of the less in-

return continuation following high volume days, suggesting the presence of private information trading in emerging markets).

219. For a detailed analysis, see Licht, supra note 8, at 596-602.

220. The seminal works include Albert S. Kyle, Continuous Auctions and Insider Trading, 53 ECONOMETRICA 1315 (1985); Anat R. Admati \& Paul Pfleiderer, A Theory of Intraday Patterns: Volume and Price Variability, 1 Rev. Fin. Stud. 3 (1988).

221. See Bhagwan Chowdhry \& Vikram Nanda, Multimarket Trading and Market Liquidity, 4 REv. Fin. STUd. 483 (1991).

222. See Ananth Madhavan, Consolidation, Fragmentation, and the Disclosure of Trading Information, 8 Rev. Fin. STUd. 579 (1995). An earlier model along similar lines is RuTH J. FreEdman, International Crosslisting: A Theoretical and Empirical Analysis (unpublished Ph.D. dissertation 1991) (on file with author). 
formed international traders. Martins' evidence strongly confirms this prediction. ${ }^{223}$

Empirical studies conducted until the late 1990s looked mostly at the impact of cross-listing on trading volume and return variance. These studies were unable to reach unequivocal conclusions. ${ }^{224}$ Martins studies equity issues by firms from emerging markets and reaches findings consistent with his theoretical predictions. ${ }^{225}$ In a carefully designed study of cross-listed Dutch stocks, Menkveld is able for the first time to provide evidence on traders who prefer to trade during overlap trading hours in New York and Amsterdam and to split their orders across markets. ${ }^{226}$ In particular, the results more strongly support the proposition that it is informed traders, rather than large liquidity traders, who split their orders across markets. ${ }^{227}$

In conclusion, cross-listing entails more than just subjecting the issuer to the host market's regulatory regime; it also subjects the host market to potentially adverse effects coming from the issuer's home county. It does not matter which market ends up with the larger portion of trading volume. In a multimarket environment, the home market is more likely to retain its informational advantage, and insiders are better able to profit from this advantage.

\section{CONCLUSION}

This article has explored a new aspect of much discussed issues in corporate governance reform and cross-listing of securities: the role of cultural and informational distance. The present analysis enriches current discussions by adding a dimension of cultural analysis, as it has developed in cultural and crosscultural psychology. The analysis offered here is not intended to replace or trump analyses that draw on other approaches, most notably, an economic analysis approach. To the contrary, this article serves to demonstrate that these lines of inquiry can, and should be combined.

223. Martins, supra note 41 , at 9 .

224. See Licht, supra note 8 , at $600-01$.

225. See MARTINS, supra note 41 , at 12.

226. See Albert J. Menkveld, Splitting Orders in Fragmented Markets Evidence From CRoss-Listed Stocks (Working Paper, 2001), available at http://www.fese.be/delavega /2001/ jvp2001_menkveld_paper.pdf.

227. Id. at 30 . 